Article

\title{
Global Validation of MODIS C6 and C6.1 Merged Aerosol Products over Diverse Vegetated Surfaces
}

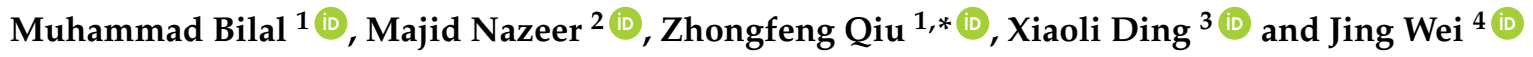 \\ 1 School of Marine Sciences, Nanjing University of Information Science \& Technology, Nanjing 210044, China; \\ muhammad.bilal@connect.polyu.hk \\ 2 Earth and Atmospheric Remote Sensing Lab. (EARL), Department of Meteorology, COMSATS Institute of \\ Information Technology, Islamabad 45550, Pakistan; majid.nazeer@comsats.edu.pk \\ 3 Department of Land Surveying and Geo-Informatics, The Hong Kong Polytechnic University, Hung Hom, \\ Kowloon 999077, Hong Kong, China; xl.ding@polyu.edu.hk \\ 4 College of Geomatics, Shandong University of Science and Technology, Qingdao 266590, China; \\ weijing_rs@163.com \\ * Correspondence: zhongfeng.qiu@nuist.edu.cn; Tel.: +86-132-5181-2371
}

Received: 9 January 2018; Accepted: 16 March 2018; Published: 19 March 2018

\begin{abstract}
In this study, the MODerate resolution Imaging Spectroradiometer (MODIS) Collections 6 and 6.1 merged Dark Target (DT) and Deep Blue (DB) aerosol products $\left(\mathrm{DTB}_{\mathrm{C} 6}\right.$ and $\left.\mathrm{DTB}_{\mathrm{C6} .1}\right)$ at $0.55 \mu \mathrm{m}$ were validated from 2004-2014 against Aerosol Robotic Network (AERONET) Version 2 Level 2.0 AOD obtained from 68 global sites located over diverse vegetated surfaces. These surfaces were categorized by static values of monthly Normalized Difference Vegetation Index (NDVI) observations obtained for the same time period from the MODIS level-3 monthly NDVI product (MOD13A3), i.e., partially / non-vegetated $\left(\mathrm{NDVI}_{\mathrm{P}} \leq 0.3\right)$, moderately-vegetated $\left(0.3<\mathrm{NDVI}_{\mathrm{M}} \leq 0.5\right)$ and densely-vegetated $\left(\mathrm{NDVI}_{\mathrm{D}}>0.5\right)$ surfaces. The $\mathrm{DTB}_{\mathrm{C} 6}$ and $\mathrm{DTB}_{\mathrm{C} 6.1}$ AOD products are accomplished by the NDVI criteria: (i) use the DT AOD retrievals for NDVI $>0.3$, (ii) use the DB AOD retrievals for NDVI $<0.2$, and (iii) use an average of the DT and DB AOD retrievals or the available one with highest quality assurance flag (DT: $\mathrm{QAF}=3$; DB: $\mathrm{QAF} \geq 2$ ) for $0.2 \leq \mathrm{NDVI} \leq 0.3$. For comparison purpose, the $\mathrm{DTB}_{\mathrm{SMS}} \mathrm{AOD}$ retrievals were included which were accomplished using the Simplified Merge Scheme, i.e., use an average of the $\mathrm{DT}_{\mathrm{C} 6.1}$ and $\mathrm{DB}_{\mathrm{C} 6.1} \mathrm{AOD}$ retrievals or the available one for all the NDVI values. For NDVI $I_{P}$ surfaces, results showed that the $\mathrm{DTB}_{\mathrm{C}}$ and $\mathrm{DTB}_{\mathrm{C} 6.1}$ AOD retrievals performed poorly over North and South America in terms of the agreement with AERONET AOD, and over Asian region in terms of retrievals quality as the small percentage of AOD retrievals were within the expected error $\left(E E= \pm(0.05+0.15 \times A O D)\right.$. For $\mathrm{NDVI}_{\mathrm{M}}$ surfaces, retrieval errors and poor quality in $\mathrm{DTB}_{\mathrm{C} 6}$ and $\mathrm{DTB}_{\mathrm{C} 6.1}$ were observed for Asian, North American and South American sites, whereas good performance, was observed for European and African sites. For $\mathrm{NDVI}_{\mathrm{D}}$ surfaces, $\mathrm{DTB}_{\mathrm{C} 6}$ does not perform well over the Asian and North American sites, although it contains retrievals only from the DT algorithm which was developed for dark surfaces. Overall, the performance of the $\mathrm{DTB}_{\mathrm{C} 6.1} \mathrm{AOD}$ retrievals was significantly improved compared to the $\mathrm{DTB}_{\mathrm{C} 6}$, but still more improvements are required over $\mathrm{NDVI}_{\mathrm{P}}, \mathrm{NDVI}_{\mathrm{M}}$ and $\mathrm{NDVI}_{\mathrm{D}}$ surfaces of Asia, $\mathrm{NDVI}_{\mathrm{M}}$ and $\mathrm{NDVI}_{\mathrm{D}}$ surfaces of North America, and $\mathrm{NDVI}_{\mathrm{M}}$ surfaces of South America. The performance of the DTB $\mathrm{DMS}_{\mathrm{SMS}}$ retrievals was better than the $\mathrm{DTB}_{\mathrm{C} 6}$ and $\mathrm{DTB}_{\mathrm{C} 6.1}$ retrievals with $11-13 \%(31 \%)$ greater number of coincident observations, 6-9\% (14-22\%) greater percentage of retrievals within the EE, and $30-100 \%(46-100 \%)$ smaller relative mean bias compared to the $\mathrm{DTB}_{\mathrm{C} 6.1}\left(\mathrm{DTB}_{\mathrm{C} 6}\right)$ at a global scale.
\end{abstract}

Keywords: AERONET; MOD04; AOD $550 \mathrm{~nm}$; DT; DB; Merged AOD $550 \mathrm{~nm}$ 


\section{Introduction}

The MODerate resolution Imaging Spectroradiometer (MODIS) is operating on both the Terra and Aqua spacecraft. It provides extensive geophysical data set for every 1 to 2 days at three spatial resolutions of $250 \mathrm{~m}, 500 \mathrm{~m}$, and $1000 \mathrm{~m}$ for 36 spectral wavelengths from 0.4 to $14.4 \mu \mathrm{m}$. The MODIS aerosol product provides daily observations of Aerosol Optical Depth (AOD) at global scale over vegetated (dark) land [1-3] and ocean surfaces [2,4] based on the Dark Target (DT) land and DT ocean algorithms, receptively, and over bright land surfaces based on the Deep Blue (DB) algorithm [5-7]. The collection 6 (C6) of MODIS level-2 operational aerosol products for Terra (MOD04) and Aqua (MYD04) includes a new Scientific Data Set (SDS) “AOD_550_Dark_Target_Deep_Blue_Combined" which represents the merged aerosol product $\left(\mathrm{DTB}_{\mathrm{C} 6}\right)$ based on the DT and DB aerosol retrieval algorithms [2,8].

For the C6 DT algorithm, pixels at $500 \mathrm{~m}$ resolutions are selected for dark vegetated surfaces using the top of atmosphere reflectance (TOA) between 0.01 and 0.25 and corrected for gas absorption. The selected pixels are organized into 400 pixels' boxes $(20 \times 20$ pixels $)$ for cloud mask, and removal of snow/ice and other bright surfaces as the $\mathrm{DT}_{\mathrm{C} 6}$ algorithm does not perform aerosol retrievals over these surfaces. The $0.66 \mu \mathrm{m}$ channel is used to separate land and water pixels, and discarding the $20 \%$ darkest and the $50 \%$ brightest pixels from the retrieval boxes. From the remaining pixels, more than 50 out of 120 pixels (remaining pixels after 70\% exclusion from the original 400) are required to perform aerosol retrievals for highest quality assurance flag $(\mathrm{QAF}=3)$, and for QAF = 2, 1, 0, more than 30, 20 and 12 pixels are required, respectively. The expected error (EE) of the DT algorithm over land is $\left.\pm\left(0.05+0.15 \times \mathrm{AOD}_{\mathrm{AERONET}}\right)\right)$ [2]. The EE represents a one standard deviation confidence interval around the retrieved AOD, i.e., about $68 \%$ of points should fall within $\pm E E$ from the true AOD, and validation studies suggest that this is met on global average [8,9]. Recently, the Collection 6.1 (C6.1) DT $_{\mathrm{C} 6.1}$ aerosol product has been released, and modifications made for C6.1 over land compared to C6 are: (i) the quality of AOD retrievals degraded to zero if more than $50 \%$ coastal pixels or $20 \%$ of water pixels are within 400 pixels' boxes $(20 \times 20$ pixels $)$, and (ii) the surface reflectance ratios for urban area were revised using MODIS operational surface reflectance product (MOD09) as described in [10]. List of modifications in the $\mathrm{DT}_{\mathrm{C} 6.1}$ algorithm is available at https:/ / modis-atmosphere.gsfc.nasa.gov / sites/default/files/ModAtmo/C061_Aerosol_Dark_Target_v2.pdf.

For the C6 DB algorithm, pixels at $1 \mathrm{~km}$ spatial resolution are masked for clouds and snow /ice surfaces, and the remaining pixels are used to calculate surface reflectance at the $0.412,0.470$, and $0.650 \mu \mathrm{m}$ channels using (i) the dynamic surface reflectance [5], or (ii) a pre-calculated surface reflectance database, or (iii) a combination of these two methods. The selection of one of these methods depends on the TOA reflectance in the $2.1 \mu \mathrm{m}$ and the Normalized Difference Vegetation Index (NDVI). The DB algorithm retrieves AOD at $1 \mathrm{~km}$ spatial resolution over dark, as well as bright urban and desert surfaces, and then aggregates the retrievals to $10 \mathrm{~km}$ spatial resolution. The EE for DB is dependent on the geometry but is approximately $0.03+0.20$ on average (i.e., the algorithms have different error characteristics) $[2,5]$. The newly released $\mathrm{DB}_{\mathrm{C} 6.1}$ aerosol product made modifications in the algorithm compared to $\mathrm{C} 6$ which are: (i) artifacts in heterogeneous terrain were reduced, (ii) surface reflectance modelling for elevated terrain was improved, (iii) regional/seasonal aerosol models were updated, (iv) metadata was updated especially for Ångström Exponent, (v) EE was updated, and (vi) internal smoke detection masks were improved. List of modifications made for the $\mathrm{DB}_{\mathrm{C} 6.1}$ algorithm is available https:/ / modis-atmosphere.gsfc.nasa.gov/sites/default/files/ModAtmo/modis_deep_ blue_c61_changes2.pdf. In this study, the EE for DT algorithm is used for all calculations.

In $\mathrm{C} 6$ and $\mathrm{C6.1}$, the new DT and DB merged (DTB $\mathrm{C}_{6}$ and $\mathrm{DTB}_{\mathrm{C} 6.1}$ ) AOD products are based on the DT and DB AOD retrievals, and the DT and DB algorithms have different spatial coverage of AOD retrievals over land due to differences in their approaches, i.e., selection of pixels, surface reflectance estimation method, and cloud mask. The purpose of this new product is to increase the spatial coverage of AOD retrievals over land while preserving the quality of the retrievals [2,8], i.e., to retrieve AOD in the same image for those regions where the DT algorithm does not retrieve due to thresholds based on 
visible-infrared channels, and cloud mask [2], and where the DB algorithm does not retrieve due to a more stringent cloud mask than DT which more often erroneously removes cloud-free pixels [5,11]. The $\mathrm{DTB}_{\mathrm{C} 6}$ and $\mathrm{DTB}_{\mathrm{C} 6.1}$ AOD products are accomplished by the NDVI criteria [2]: (i) use the DT AOD retrievals for NDVI $>0.3$, (ii) use the DB AOD retrievals for NDVI $<0.2$, and (iii) use an average of the DT and DB AOD retrievals or the available one with highest quality assurance (DT: QAF = 3; $\mathrm{DB}: \mathrm{QAF} \geq 2$ ) for $0.2 \leq \mathrm{NDVI} \leq 0.3$. The newly released $\mathrm{DTB}_{\mathrm{C} 6.1}$ AOD product is based on the same approach as the $\mathrm{DTB}_{\mathrm{C} 6}$, but the modifications in $\mathrm{DT}_{\mathrm{C} 6.1}$ and $\mathrm{DB}_{\mathrm{C} 6.1} \mathrm{AOD}$ retrievals make it different than the DTB $\mathrm{C}_{6}$.

Recently, Bilal et al. [9] have introduced three new methods to improve the spatiotemporal coverage and reduce the errors in the $\mathrm{DTB}_{\mathrm{C} 6}$ merged aerosol product. These methods were validated against AERONET sites located on mixed surfaces and compared with the DTB $\mathrm{C}_{6}$. This study concluded that the DTB $\mathrm{SMS}_{\mathrm{S}}\left(\mathrm{DTB}_{\mathrm{M} 1}\right.$ in [9]) method, which is based on the Simplified Merge Scheme (SMS), is robust over mixed surfaces as (i) it is independent of NDVI, (ii) increases the number of coincident observations, (iii) reduces the RMSE, and (iv) increases the percentage of retrievals within the EE compared to the other proposed methods in [9] and $\mathrm{DTB}_{\mathrm{C} 6}$, and therefore, recommended to use operationally at a global scale. The $\mathrm{DTB}_{\mathrm{C} 6}, \mathrm{DTB}_{\mathrm{C} 6.1}$, and $\mathrm{DTB}_{\mathrm{SMS}} \mathrm{AOD}$ retrievals have not been validated yet at regional to global scales for AERONET sites located over diverse vegetated surfaces or over surfaces with the same NDVI values. Therefore, the objective of this study is to validate the $\mathrm{DTB}_{\mathrm{C} 6}$, $\mathrm{DTB}_{\mathrm{C} 6.1}$, and $\mathrm{DTB}_{\mathrm{SMS}} \mathrm{AOD}$ retrievals over diverse vegetated surfaces, i.e., partially/non-vegetated surfaces $\left(\mathrm{NDVI}_{\mathrm{P}} \leq 0.3\right)$, moderately-vegetated surfaces $\left(0.3<\mathrm{NDVI}_{\mathrm{M}} \leq 0.5\right)$ and densely-vegetated surfaces $\left(\mathrm{NDVI}_{\mathrm{D}}>0.5\right)$ against 68 AERONET sites at regional to global scales from 2004-2014. The present study is different than the previous one [9], as first, land surfaces are categorized based on the NDVI values, and then, AOD observations obtained from $\mathrm{DTB}_{\mathrm{C} 6}, \mathrm{DTB}_{\mathrm{C} 6.1}$ and $\mathrm{DTB}_{\mathrm{SMS}}$ were validated against AERONET sites located over diverse vegetated surfaces. A complete list of abbreviations used in the manuscript is provided in Appendix A.

\section{Dataset}

In this study, Terra MODIS C6 and C6.1 level-2 operational aerosol products (MOD04) at $10 \mathrm{~km}$ spatial resolution were downloaded from "the Level-1 and Atmosphere Archive \& Distribution System (LAADS) Distributed Active Archive Center (DAAC)" (https://ladsweb.modaps.eosdis.nasa.gov/) at global scale to obtain the $\mathrm{DTB}_{\mathrm{C} 6}, \mathrm{DT}_{\mathrm{C} 6.1}$, the $\mathrm{DB}_{\mathrm{C} 6.1}$, and the $\mathrm{DTB}_{\mathrm{C} 6.1}$ AOD retrievals from 2004 to 2014 . MODIS C6 monthly level-3 Normalized Difference Vegetation Index (NDVI) product (MOD13A3) was downloaded to categorize diverse vegetated surfaces. For validation of satellite AOD retrievals, AERONET [12-15] Version 2 Level 2.0 (cloud-screened and quality-assured) [16] AOD data were downloaded from the AERONET website (http:/ / aeronet.gsfc.nasa.gov) for all the 68 sites and the respective time periods. The detailed summary of the data set is provided in Table 1, and list of AERONET sites used in this study is given in Table 2.

Table 1. Summary of data set used in the current study.

\begin{tabular}{ccc}
\hline Data & Scientific Data Set (SDS) & Contents \\
\hline AERONET & Version 2 Level 2.0 & AOD \\
\hline MOD04 C6/C6.1 & Optical_Depth_Land_And_Ocean & $\begin{array}{c}\text { AOD of QAF = 3 over land and QAF = 1 } \\
\text { to 3 over ocean }\end{array}$ \\
\hline & Deep_Blue_Aerosol_Optical_Depth_550_Land_Best_Estimate & AOD of QAF $\geq 2$ over land \\
\hline & AOD_550_Dark_Target_Deep_Blue_Combined & AOD of QAF = 1 to 3 over land and ocean \\
\hline AOD_550_Dark_Target_Deep_Blue_Combined_QAF_Flag & QAF = 1 to 3 \\
\hline 1 km NDVI & Monthly NDVI \\
\hline
\end{tabular}


Table 2. List of AEROENT sites used in this study.

\begin{tabular}{|c|c|c|c|c|c|}
\hline Site Name & Lat. $\left({ }^{\circ} \mathrm{N}\right)$ & Long. $\left({ }^{\circ} \mathrm{E}\right)$ & Site Name & Lat. $\left({ }^{\circ} \mathrm{N}\right)$ & Long. $\left({ }^{\circ} \mathrm{E}\right)$ \\
\hline \multicolumn{6}{|c|}{ African Sites } \\
\hline CRPSM Malindi & -2.9960 & 40.1940 & Pretoria CSIR & -25.7570 & 28.2800 \\
\hline Gorongosa & -18.9780 & 34.3510 & Skukuza & -24.9920 & 31.5870 \\
\hline ICIPE-Mbita & -0.4170 & 34.2000 & Wits University & -26.1920 & 28.0290 \\
\hline \multicolumn{6}{|c|}{ Asian Sites } \\
\hline Beijing & 39.977 & 116.381 & NhaTran & 12.205 & 109.21 \\
\hline Chiang Mai Met Sta. & 18.7710 & 98.9720 & Pune & 18.5370 & 73.8050 \\
\hline Jaipur & 26.9060 & 75.8060 & Silpakorn Univ & 13.8190 & 100.0410 \\
\hline Kanpur & 26.5130 & 80.2320 & Ubon Ratchathani & 15.2460 & 104.8710 \\
\hline NGHIA_DO & 21.0480 & 105.8000 & & & \\
\hline \multicolumn{6}{|c|}{ European Sites } \\
\hline Arcachon & 44.6640 & -1.1630 & Leipzig & 51.3520 & 12.4350 \\
\hline Aubiere LAMP & 45.7610 & 3.1110 & Lille & 50.6120 & 3.1420 \\
\hline Avignon & 43.9330 & 4.878 & Minsk & 53.920 & 27.601 \\
\hline Brussels & 50.7830 & 4.350 & Moscow MSU MO & 55.700 & 37.510 \\
\hline Cabauw & 51.9710 & 4.9270 & Munich University & 48.1480 & 11.5730 \\
\hline Carpentras & 44.0830 & 5.0580 & OHP OBSERVATOIRE & 43.9350 & 5.710 \\
\hline Chilbolton & 51.1440 & -1.4370 & Palaiseau & 48.700 & 2.2080 \\
\hline Granada & 37.1640 & -3.6050 & Paris & 48.8670 & 2.3330 \\
\hline Hamburg & 53.5680 & 9.9730 & Rome Tor Vergata & 41.840 & 12.647 \\
\hline Ispra & 45.8030 & 8.6270 & Toravere & 58.2550 & 26.460 \\
\hline Kanzelhohe Obs. & 46.6780 & 13.9070 & TUBITAK UZAY Ankara & 39.8910 & 32.7780 \\
\hline \multicolumn{6}{|c|}{ North American Sites } \\
\hline Ames & 42.0210 & -93.7750 & GSFC & 38.9920 & -76.8400 \\
\hline Appalachian State & 36.2150 & -81.6940 & Harvard Forest & 42.5320 & -72.1880 \\
\hline Billerica & 42.5280 & -71.2690 & KONZA EDC & 39.1020 & -96.6100 \\
\hline BONDVILLE & 40.0530 & -88.3720 & Missoula & 46.9170 & -114.0830 \\
\hline Bozeman & 45.6620 & -111.0450 & Rimrock & 46.4870 & -116.9920 \\
\hline BSRN_BAO Boulder & 40.0450 & -105.0060 & Sevilleta & 34.3550 & -106.8850 \\
\hline CalTech & 34.1370 & -118.1260 & Sioux Falls & 43.7360 & -96.6260 \\
\hline Dayton & 39.7760 & -84.1100 & TABLE MOUNTAIN CA & 34.3800 & -117.6800 \\
\hline Frenchman Flat & 36.8090 & -115.9350 & Tucson & 32.2330 & -110.9530 \\
\hline Fresno & 36.7820 & -119.7730 & UCSB & 34.4150 & -119.8450 \\
\hline Georgia Tech & 33.7800 & -84.4000 & Univ. of Houston & 29.7180 & -95.3420 \\
\hline Grand Forks & 47.9120 & -97.3250 & & & \\
\hline \multicolumn{6}{|c|}{ South American Sites } \\
\hline Alta Floresta & -9.8710 & -56.1040 & CUIABA-MIRANDA & -15.7290 & -56.0210 \\
\hline Campo Grande SONDA & -20.4380 & -54.5380 & Manaus EMBRAPA & -2.8910 & -59.9700 \\
\hline CASLEO & -31.7990 & -69.3060 & Rio Branco & -9.9570 & -67.8690 \\
\hline CEILAP-BA & -34.5670 & -58.5000 & Sao Martinho SONDA & -29.4430 & -53.8230 \\
\hline
\end{tabular}

\section{Methods}

In this study, the $\mathrm{DTB}_{\mathrm{C} 6}, \mathrm{DTB}_{\mathrm{C} 6.1}$, and $\mathrm{DTB}_{\mathrm{SMS}} \mathrm{AOD}$ retrievals were validated against 68 AERONET sites located over diverse vegetated surfaces in Asia, Europe, Africa, North and South America from 2004 to 2014. The methodology of this study is based on the following steps:

(i) The $\mathrm{DTB}_{\mathrm{C} 6}$ and $\mathrm{DTB}_{\mathrm{C} 6.1} \mathrm{AOD}$ retrievals were obtained from the SDS "AOD_550_Dark_ Target_Deep_Blue_Combined" which were filtered for highest quality assurance flag (QAF =3) using the SDS “AOD_550_Dark_Target_Deep_Blue_Combined_QA_Flag".

(ii) For the $\mathrm{DTB}_{\mathrm{SMS}}$, the $\mathrm{DT}_{\mathrm{C} 6.1}$ highest quality assurance flag $(\mathrm{QAF}=3) \mathrm{AOD}$ retrievals were obtained from the SDS “Optical_Depth_Land_And_Ocean" and the $\mathrm{DB}_{\mathrm{C} 6.1}$ highest quality assurance flag $(\mathrm{QAF} \geq 2)$ AOD retrievals were obtained from the SDS “Deep_Blue_Aerosol_Optical_Depth_ 550_Land_Best_Estimate". The DTB ${ }_{\text {SMS }}$ product is generated by Simplified Merge Scheme (SMS) $[9,17]$, i.e. "use an average of the $\mathrm{DT}_{\mathrm{C} 6.1}$ and $\mathrm{DB}_{\mathrm{C} 6.1} \mathrm{AOD}$ retrievals or the available one for all the NDVI values [9]" which is independent of NDVI.

(iii) AERONET measurements do not provide AOD data at $0.55 \mu \mathrm{m}$, therefore, AOD data were interpolated to $0.55 \mu \mathrm{m}$ using Ångström exponent $440-675 \mathrm{~nm}\left(\alpha_{440-675}\right)$ [11]. 
(iv) To increase temporal coverage of AOD data, retrievals were defined as the average of at least two pixels of $\mathrm{DTB}_{\mathrm{C} 6} / \mathrm{DTB}_{\mathrm{C} 6.1} / \mathrm{DTB}_{\mathrm{SMS}}$ within a spatial region of $3 \times 3$ pixels (at least 2 out of 9 pixels) centered on the AERONET site and the average of at least two AERONET AOD measurements between 10:00 and 12:00 local solar time.

(v) The $\mathrm{DTB}_{\mathrm{C} 6}, \mathrm{DTB}_{\mathrm{C} 6.1}$, and $\mathrm{DTB}_{\mathrm{SMS}} \mathrm{AOD}$ retrievals were filtered for three diverse types of land surfaces, i.e., partially/non-vegetated $\left(\mathrm{NDVI}_{\mathrm{P}} \leq 0.3\right)$, moderated-vegetated $\left(0.3<\mathrm{NDVI}_{\mathrm{M}} \leq 0.5\right)$ and dense-vegetated $\left(\mathrm{NDVI}_{\mathrm{D}}>0.5\right)$ surfaces defined by static values of monthly NDVI observations obtained from the MOD13A3 C6 L3 product. Bilal and Nichol [18] found that dynamic values of NDVI can improve the accuracy of the DTB $\mathrm{C}_{6}$ AOD retrievals, but in this study, static values of NDVI were used as the $\mathrm{DTB}_{\mathrm{C} 6}$ and $\mathrm{DTB}_{\mathrm{C} 6.1}$ products are based on these values $[2,8]$.

(vi) The errors and quality of the retrievals were reported using the relative mean bias (RMB, Equation (1)), root mean square error (RMSE, Equation (2)), and the expected error (EE, Equation (3)) of the DT algorithm over land. To compare different methods statistically, the percent relative differences in N, R, EE, RMSE, and RMB R are calculated using Equation (4)

$$
\begin{aligned}
& R \mathrm{MB}=\left(\frac{\overline{\mathrm{AOD}}_{(\mathrm{MODIS})}-\overline{\mathrm{AOD}}_{(\mathrm{AERONET})}}{\overline{\mathrm{AOD}}_{(\mathrm{AERONET})}}\right) \\
& \mathrm{RMSE}=\sqrt{\frac{1}{\mathrm{n}} \sum_{\mathrm{i}=1}^{\mathrm{n}}\left(\mathrm{AOD}_{(\mathrm{MODIS}) \mathrm{i}}-\mathrm{AOD}_{(\mathrm{AERONET}) \mathrm{i}}\right)^{2}} \\
& \mathrm{EE}= \pm\left(0.05+0.15 \times \mathrm{AOD}_{(\mathrm{AERONET})}\right) \\
& \% \text { Relative Difference }=\left(\frac{\text { DTB }_{\mathrm{C} 6.1}-\mathrm{DTB}_{\mathrm{SMS}}}{\mathrm{DTB}_{\mathrm{C} 6.1}}\right) \times 100
\end{aligned}
$$

\section{Results}

To point out an efficient and robust aerosol product among the $\mathrm{DTB}_{\mathrm{C} 6}, \mathrm{DTB}_{\mathrm{C} 6.1}$, and $\mathrm{DTB}_{\mathrm{SMS}}$, the following criteria $[8,9]$ are used in the following sections: if either of the product has relative difference using Equation (4) greater than (i) 5\% for the coincident observations (N), (ii) $5 \%$ for the percentage of retrievals within the EE, (iii) $5 \%$ for the correlation coefficient, and less than (iv) 5\% for the RMSE and $\mathrm{RMB}$, then it will be considered to perform best over the specific surface type and region.

\subsection{Validation of $D T B_{C 6}, D T B_{C 6.1}$, and DTB $B_{S M S} A O D$ over Diverse Vegetated Surfaces at Regional Scale}

\subsubsection{Validation of AOD Retrievals over Diverse Vegetated Surfaces of Asia}

Validation of the $\mathrm{DTB}_{\mathrm{C} 6}, \mathrm{DTB}_{\mathrm{C} 6.1}$, and $\mathrm{DTB}_{\mathrm{SMS}}$ AOD retrievals was conducted over 9 Asian sites (Table 2) located at diverse vegetated surfaces (Figure 1). In Figure 1, the dashed lines represent the EE envelope and the solid line has a slope of unity. The large numbers of AOD measurements from AERONET were available for $\mathrm{NDVI}_{M}$ surfaces $(\mathrm{N}=4485)$ followed by $\mathrm{NDVI}_{\mathrm{P}}$ surfaces $(\mathrm{N}=2933)$ and $\mathrm{NDVI}_{D}$ surfaces $(\mathrm{N}=726)$. These $A O D$ measurements for $\mathrm{NDVI}_{\mathrm{P}}$ and $\mathrm{NDVI}_{\mathrm{M}}$ surfaces were available from January to December and for $\mathrm{NDVI}_{\mathrm{D}}$ surfaces were available from June to November. AERONET has large numbers of $\mathrm{AOD}$ measurements for $\mathrm{NDVI}_{\mathrm{M}}$ surfaces, whereas, the $\mathrm{DTB}_{\mathrm{C} 6}$ product has $31.91 \%$ and $27.02 \%$ more retrievals over NDVI $_{P}$ surfaces $(2465 / 2933 \times 100=84.04 \%$ ) (Figure 1a) than the $\mathrm{NDVI}_{\mathrm{M}}$ (Figure 1b: 52.13\%) and $\mathrm{NDVI}_{\mathrm{D}}$ (Figure 1c: $57.02 \%$ ) surfaces, respectively. The DTB ${ }_{\mathrm{C} 6} \mathrm{AOD}$ retrievals have correlation coefficient $\geq 0.88$ for all the surfaces, whereas the retrievals were performed well over $\mathrm{NDVI}_{\mathrm{M}}$ surfaces as the large percentage of retrievals $(63 \%)$ were within the EE for these surfaces compared to the $\operatorname{NDVI}_{P}(51 \%)$ and $\mathrm{NDVI}_{\mathrm{D}}(51 \%)$ surfaces. This was also supported by low 
RMB (0.11) for NDVI $_{M}$ surfaces which were $35 \%$ and $61 \%$ lower than RMB for $\operatorname{NDVI}_{P}(0.17)$ and $\mathrm{NDVI}_{\mathrm{D}}(0.28)$ surfaces, respectively.

For DTB $\mathrm{C}_{\mathrm{C} .1}$, fraction of observations coincident with AERONET was $91.58 \%$ for the NDVI surfaces (Figure 1d), $70.61 \%$ for the $\mathrm{NDVI}_{\mathrm{M}}$ surfaces (Figure 1e), and $74.66 \%$ for the $\mathrm{NDVI}_{\mathrm{D}}$ surfaces (Figure 1f) which were increased by $7.54 \%, 18.48 \%$ and $17.64 \%$, respectively, compared to the DTB C6 $_{\text {. }}$ The percentage of retrievals within the EE increased from $51 \%$ to $57 \%, 63 \%$ to $66 \%$, and $51 \%$ to $58 \%$, the RMSE decreased from 0.232 to $0.194,0.198$ to 0.197 , and 0.200 to 0.176 , and the RMB decreased from 0.17 to $-0.01,0.11$ to 0.09 , and 0.28 to 0.22 for $\mathrm{NDVI}_{P}, \mathrm{NDVI}_{\mathrm{M}}$ and $\mathrm{NDVI}_{\mathrm{D}}$ surfaces, respectively. The $\mathrm{DTB}_{\mathrm{C} 6.1}$ AOD retrievals performed better over $\mathrm{NDVI}_{\mathrm{P}}$ surfaces in terms of RMB, $\mathrm{NDVI}_{\mathrm{M}}$ surfaces in terms of greater numbers of collocations, and $\mathrm{NDVI}_{\mathrm{D}}$ surfaces in terms greater percentage within the EE compared to the $\mathrm{DTB}_{\mathrm{C} 6}$. However, still more improvements in the $\mathrm{DT}_{\mathrm{C} 6.1}$ and $\mathrm{DB}_{\mathrm{C} 6.1}$ are required for all these surfaces.

For DTB $\mathrm{SMS}_{\mathrm{S}}$, results show significant improvements in spatiotemporal coverage as the fractions of observations coincident with AERONET measurements were $96.25 \%$ for the $\mathrm{NDVI}_{\mathrm{P}}$ surfaces (Figure 1d), $74.31 \%$ for the $\mathrm{NDVI}_{\mathrm{M}}$ surfaces (Figure 1e), and $78.37 \%$ for the $\mathrm{NDVI}_{\mathrm{D}}$ surfaces (Figure 1f) which were increased by $4.67 \%(16.21 \%), 3.70 \%(22.18 \%)$, and $3.71 \%(17.64 \%)$, respectively, compared to the $\mathrm{DTB}_{\mathrm{C} 6.1}\left(\mathrm{DTB}_{\mathrm{C} 6}\right)$. The quality of the $\mathrm{DTB}_{\mathrm{SMS}} \mathrm{AOD}$ retrievals was improved as the percentage of retrievals within the EE increased by 7-12\% (20-27\%), RMSE decreased by $4-6 \%$ (18-19\%), and RMB decreased by $4-18 \%$ (36-54\%). Improvements were observed in DTB SMS $_{\text {in }}$ in terms of large percentage of retrievals within the EE, a number of collocations and RMB were observed for NDVI $I_{P}$ and $\mathrm{NDVI}_{\mathrm{D}}$ surfaces compared to the $\mathrm{DTB}_{\mathrm{C} 6}$ and $\mathrm{DTB}_{\mathrm{C} 6.1}$ AOD retrievals. Overall, the performance of the $\mathrm{DTB}_{\mathrm{SMS}}$ product was better than the $\mathrm{DTB}_{\mathrm{C} 6}$ and $\mathrm{DTB}_{\mathrm{C} 6.1}$ products over Asian sites located over diverse vegetated surfaces.

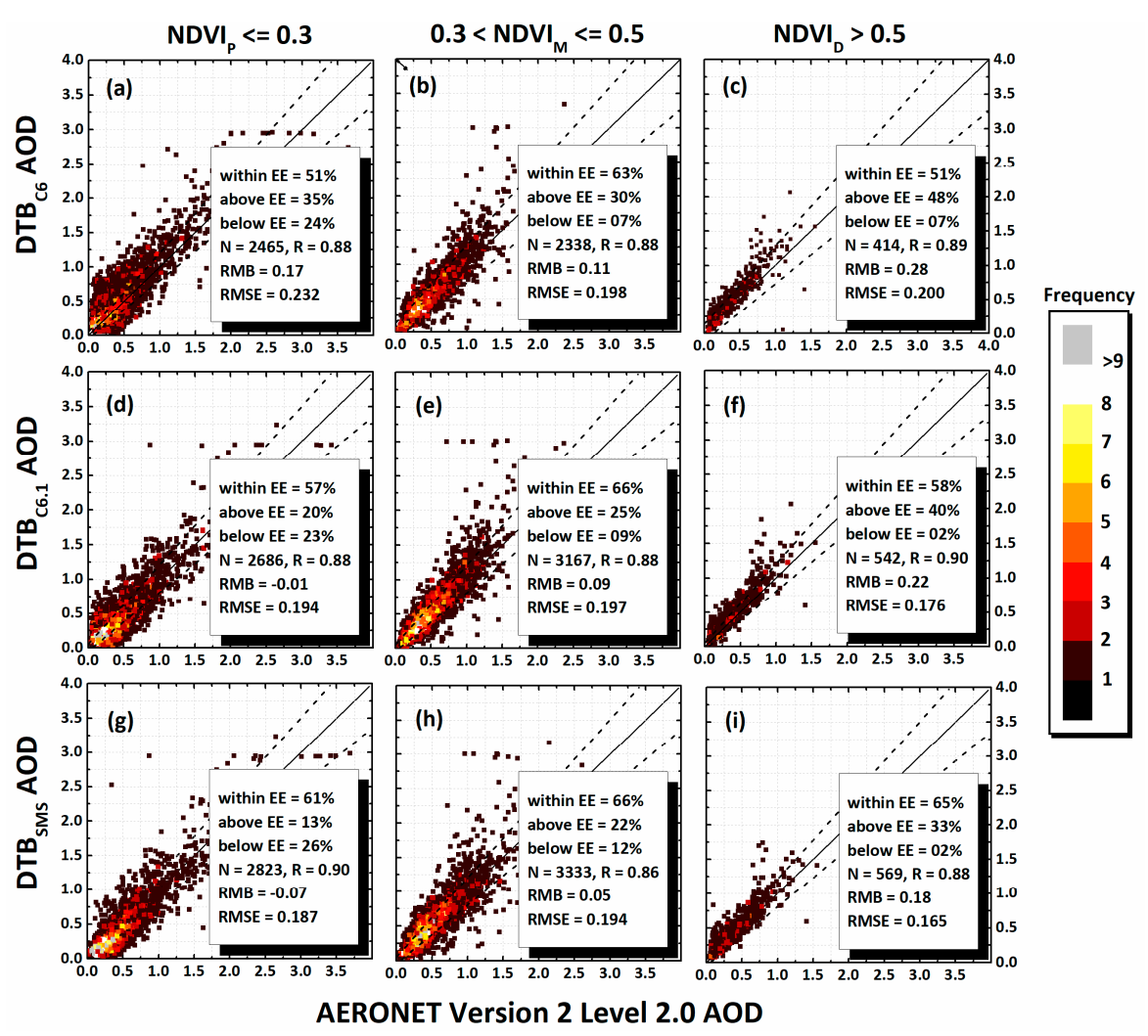

Figure 1. Validation of the $\mathrm{DTB}_{\mathrm{C} 6}(\mathbf{a}-\mathbf{c}), \mathrm{DTB}_{\mathrm{C} 6.1}(\mathbf{d}-\mathbf{f})$ and $\mathrm{DTB}_{\mathrm{SMS}}(\mathbf{g}-\mathbf{i}) \mathrm{AOD}$ retrievals against AERONET V2 L2 AOD measurements for Asian sites located over $\mathrm{NDVI}_{\mathrm{P}}, \mathrm{NDVI}_{\mathrm{M}}$, and $\mathrm{NDVI}_{\mathrm{D}}$ surfaces. Where dashed lines represent the EE envelope and the solid line represents the1:1 line. 


\subsubsection{Validation of AOD Retrievals over Diverse Vegetated Surfaces of Africa}

Total 241, 2929, and 749 AERONET AOD measurements were available for $\mathrm{NDVI}_{\mathrm{P}}, \mathrm{NDVI}_{\mathrm{M}}$, and $\mathrm{NDVI}_{\mathrm{D}}$ surfaces, respectively, and these were available from February to August for NDVI $\mathrm{P}_{\mathrm{P}}$ surfaces, and January to December for $\mathrm{NDVI}_{\mathrm{M}}$ and $\mathrm{NDVI}_{\mathrm{D}}$ surfaces. Like the Asian sites, large numbers of coincident observations were observed for the $\mathrm{NDVI}_{\mathrm{M}}$ surfaces (Figure 2b), but dissimilarly, the numbers of coincident observations of $\mathrm{DTB}_{\mathrm{C} 6.1}$ for the $\mathrm{NDVI}_{\mathrm{P}}$ surfaces (Figure 2a) were lower than the $\mathrm{NDVI}_{\mathrm{D}}$ surfaces (Figure 2c). This indicates that most of the African sites were located over vegetated surfaces (NDVI > 0.3) and this might be a reason for having large numbers of measurements for NDVI $>0.3$. The $\mathrm{DTB}_{\mathrm{C} 6.1}\left(\mathrm{DTB}_{\mathrm{C} 6}\right)$ AOD retrievals were available from $64 \%(56 \%)$ to $67 \%(60 \%)$ of the AERONET measurements, and the percentage of the retrievals within the EE and correlation were increased, and the RMSE and RMB were decreased from bright to dark surfaces. Figure $2 \mathrm{~g}-\mathrm{i}$ shows that the correlation coefficient, RMSE, RMB, and the percentage of retrievals within the EE of the $\mathrm{DTB}_{\mathrm{SMS}}$ were within $5 \%$ of the $\mathrm{DTB}_{\mathrm{C} 6}$ and $\mathrm{DTB}_{\mathrm{C} 6.1}$, whereas, the numbers of collocations were increased by $14-24 \%$ compared to the $\mathrm{DTB}_{\mathrm{C} 6}$. Overall, no significant improvements were observed in $\mathrm{DTB}_{\mathrm{C} 6.1}$ and $\mathrm{DTB}_{\mathrm{SMS}}$ AOD retrievals compared to the $\mathrm{DTB}_{\mathrm{C} 6}$ in terms of the agreement with the AERONET measurements, RMSE, RMB, and the percentage of retrievals within the EE.
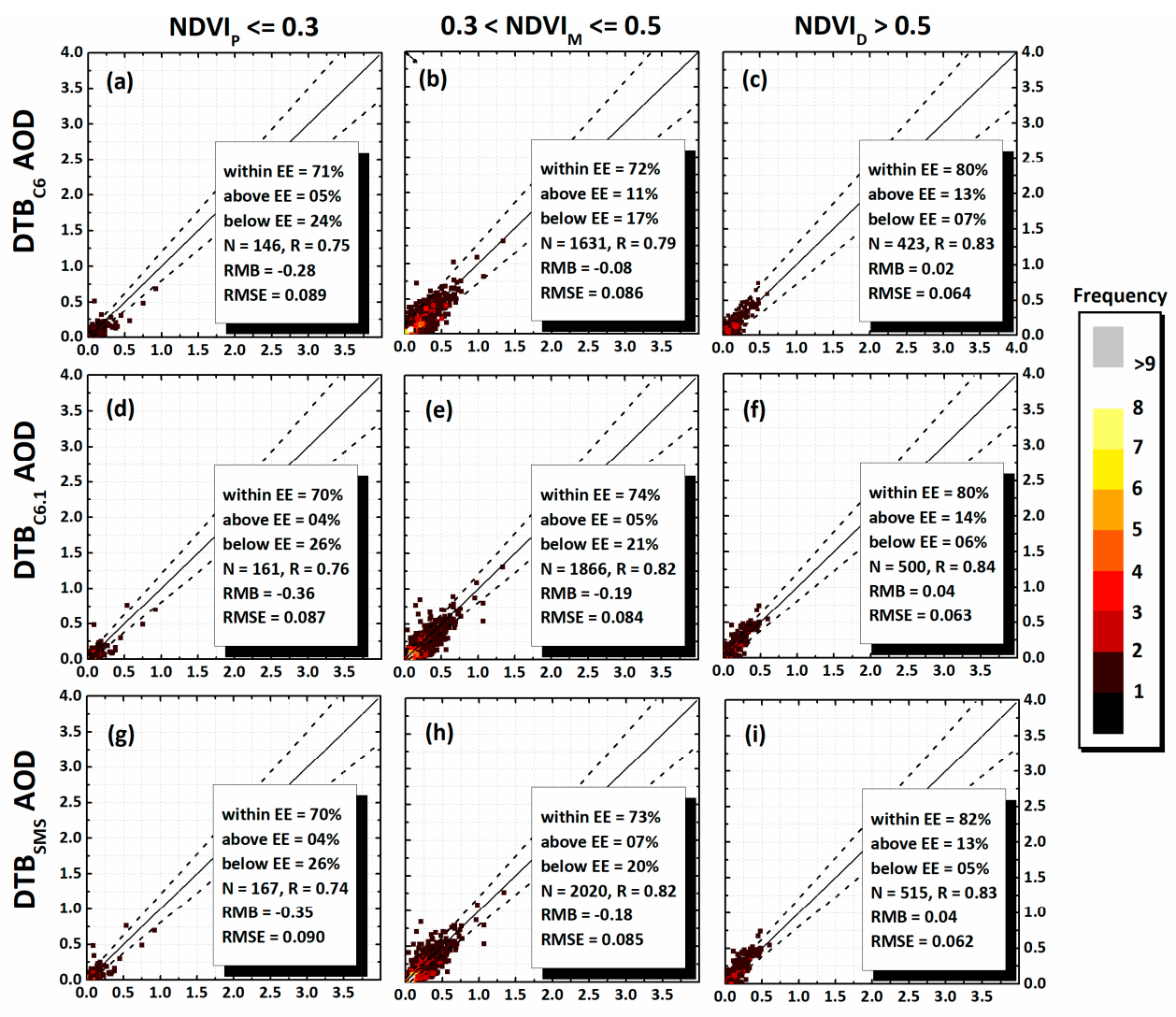

AERONET Version 2 Level 2.0 AOD

Figure 2. Same as Figure 1, but for African sites.

\subsubsection{Validation of AOD Retrievals over Diverse Vegetated Surfaces of Europe}

Most of the European AEORNET sites used in this study were located over moderate to densely vegetated surfaces and large numbers of AOD measurements were available over these sites $\left(\mathrm{NDVI}_{\mathrm{M}}=9309\right.$ and $\left.\mathrm{NDVI}_{\mathrm{D}}=8533\right)$, compared to the sites located over $\mathrm{NDVI}_{\mathrm{P}}$ surfaces $(\mathrm{N}=3347)$. The AOD measurements followed the same pattern as the African sites, i.e., the large numbers of measurements were available for $\mathrm{NDVI}_{M}$ surfaces followed by $\mathrm{NDVI}_{D}$ and $\mathrm{NDVI}_{\mathrm{P}}$ surfaces, but 
overall, these measurements were much more in numbers than those were available for Asian and African sites. Figure 3 shows that the performance of the DTB ${ }_{C 6}$ AOD retrievals was better for $\mathrm{NDVI}_{M}$ surfaces as the percentage of retrievals within the EE was 70 which meets the requirements of the EE (Figure $3 b$ ), compared to the retrievals for $\mathrm{NDVI}_{\mathrm{P}}$ and $\mathrm{NDVI}_{\mathrm{D}}$ surfaces. For $\mathrm{NDVI}_{\mathrm{P}}$ to $\mathrm{NDVI}_{\mathrm{D}}$ surfaces, $28 \%$ to $36 \%$ of the retrievals were above the EE which led to $24 \%$ to $38 \%$ an average overestimation in the DTBC6 AOD retrievals, and maximum overestimation was observed for the NDVI $_{D}$ surfaces, and similar results were also observed for Asian sites. Figure $3 \mathrm{~d}-\mathrm{f}$ shows improvements in the DTB $\mathrm{C}_{\mathrm{C} .1}$ $\mathrm{AOD}$ retrievals compared to the $\mathrm{DTB}_{\mathrm{C} 6}$ as the percentage of retrievals within the EE increased from $59 \%$ to $70 \%, 70 \%$ to $80 \%$, and $62 \%$ to $71 \%$, the number of collocations increased from 1885 to 2070,5952 to 7007, and 5297 to 6278, and RMSE (RMB) decreased from $0.109(0.24)$ to $0.086(0.18), 0.089(0.31)$ to $0.075(0.18)$, and $0.097(0.38)$ to $0.085(0.27)$ for $\mathrm{NDVI}_{\mathrm{P}}, \mathrm{NDVI}_{\mathrm{M}}$ and $\mathrm{NDVI}_{\mathrm{D}}$ surfaces, respectively. These results indicate significant improvements in the $\mathrm{DTB}_{\mathrm{C} 6.1}$ over European sites due to revised

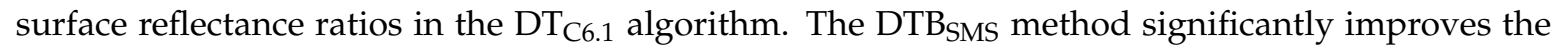
results in terms of the number of collocations, the large percentage within the EE, and small RMSE and RMB. The number of collocations increased by $42 \%(56 \%), 25 \%(48 \%)$, and $22 \%$ (45\%), the percentage within the EE increased by $10 \%(31 \%), 4 \%(19 \%)$, and $10 \%(26 \%)$, the RMSE decreased by $6 \%(26 \%), 8 \%$ (22\%), and 8\% (20\%), and the RMB decreased by 67\% (75\%), 56\% (74\%), and 44\% (61\%) for NDVI $\mathrm{NDVI}_{\mathrm{M}}$, and $\mathrm{NDVI}_{\mathrm{D}}$ surfaces, respectively, compared to the DTB $\mathrm{C6.1}$ (DTB 6 ) AOD product. Overall, the DTB $\mathrm{SMS}_{\mathrm{S}}$ method was robust and performed well over European sites for all types of surfaces used in this study (Table 2), compared to the $\mathrm{DTB}_{\mathrm{C} 6}$ and $\mathrm{DTB}_{\mathrm{C} 6.1}$ products.

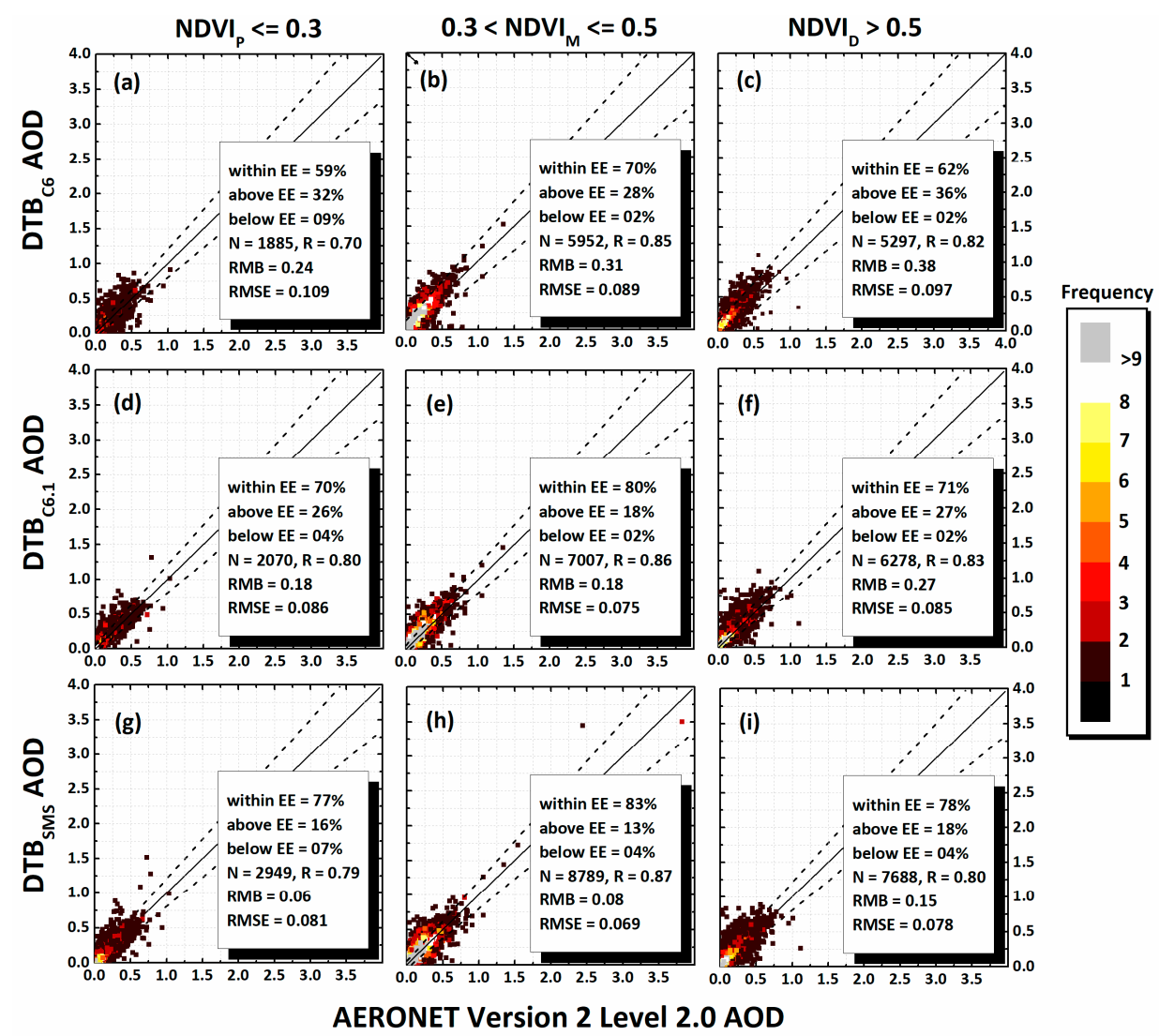

Figure 3. Same as Figure 1, but for European sites.

\subsubsection{Validation of AOD Retrievals over Diverse Vegetated Surfaces of North America}

The DTB $_{\mathrm{C} 6}$ (Figure $4 \mathrm{a}$ ) and $\mathrm{DTB}_{\mathrm{C} 6.1}$ (Figure $4 \mathrm{~d}$ ) AOD retrievals for $\mathrm{NDVI}_{\mathrm{P}}$ surfaces meet the requirements of the $\mathrm{EE}$ as $73 \%$ and $75 \%$ of the retrievals were within the $\mathrm{EE}$, respectively, whereas the 
percentage of retrievals within the $\mathrm{EE}$ for $\mathrm{NDVI}_{\mathrm{M}}$ and $\mathrm{NDVI}_{\mathrm{D}}$ surfaces was much lower. It is worth mentioning that the $\mathrm{DTB}_{\mathrm{C} 6}$ and $\mathrm{DTB}_{\mathrm{C} 6.1} \mathrm{AOD}$ retrievals have significantly larger error $(\mathrm{RMB}=0.77$ and 0.61) for $\mathrm{NDVI}_{M}$ surfaces (Figure $4 \mathrm{~b}, \mathrm{e}$ ), compared to the $\mathrm{NDVI}_{\mathrm{P}}$ (Figure $4 \mathrm{a}, \mathrm{d}$ ) and $\mathrm{NDVI}_{\mathrm{D}}($ Figure $4 \mathrm{c}, \mathrm{f})$ surfaces. Significant overestimation and underestimation were observed in $\mathrm{DTB}_{\mathrm{C} 6.1}$ AOD retrievals compared to the $\mathrm{DTB}_{\mathrm{C} 6}$. The performance of the $\mathrm{DTB}_{\mathrm{SMS}}$ was same as the $\mathrm{DTB}_{\mathrm{C} 6}$ in terms of correlation, whereas the number of collocations increased by 10-22\% (131-179\%), the percentage of retrievals within the EE increased by 3-15\% (7-29\%), and RMB decreased by 8-28\% (28-80\%) for the DTBSMS, compared to the $\mathrm{DTB}_{\mathrm{C} 6.1}\left(\mathrm{DTB}_{\mathrm{C} 6}\right)$. Overall, low performance was observed for all the methods compared to the other regions which indicate the low performance of the DT and DB algorithms.

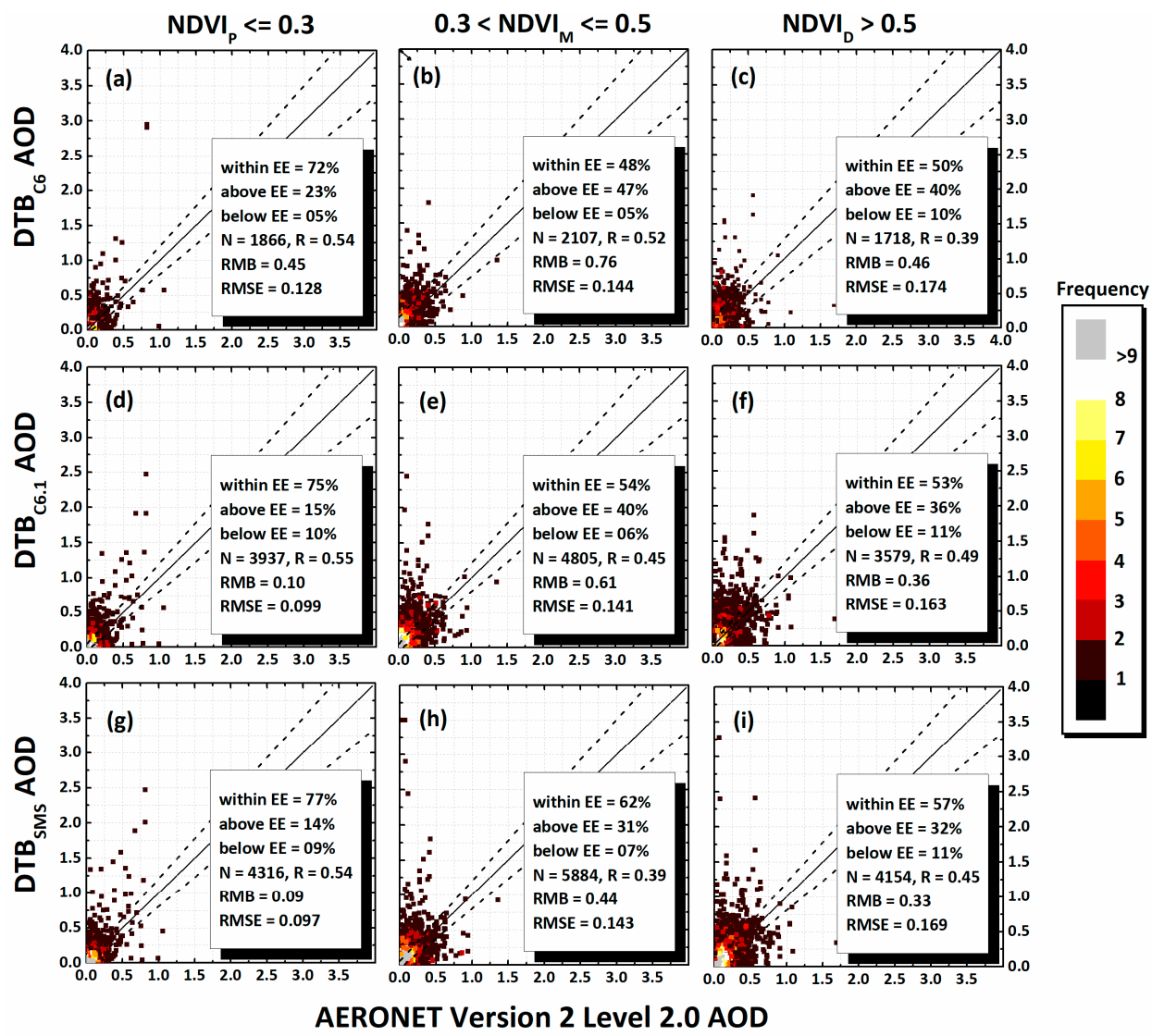

Figure 4. Same as Figure 1, but for North American sites.

\subsubsection{Validation of AOD Retrievals over Diverse Vegetated Surfaces of South America}

Figure 5 shows that AOD level for NDVI surfaces (Figure 5a,d,g) was much lower than to those observed for $\mathrm{NDVI}_{\mathrm{M}}$ (Figure $5 \mathrm{~b}, \mathrm{e}, \mathrm{h}$ ) and $\mathrm{NDVI}_{\mathrm{D}}$ (Figure $5 \mathrm{c}, \mathrm{f}, \mathrm{i}$ ) surfaces. Although the percentage of

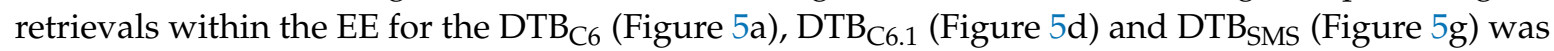
higher for $\mathrm{NDVI}_{\mathrm{P}}$ surfaces than the $\mathrm{NDVI}_{\mathrm{M}}$ surfaces, but overall, the performance of these methods was lower for $\mathrm{NDVI}_{\mathrm{P}}$ surfaces as they have large $\mathrm{RMB}$ and low correlation. Like other regions, the performance of the $\mathrm{DTB}_{\mathrm{SMS}}$ was better than the $\mathrm{DTB}_{\mathrm{C} 6}$ and $\mathrm{DTB}_{\mathrm{C} 6.1}$ as the percentage of retrievals within the EE and number of collocations were increased, and RMB was decreased. The DTB $\mathrm{SMS}_{\mathrm{S}}$ has a large number of collocations and small RMB for all the surfaces, and greater percentage within the EE for $\mathrm{NDVI}_{\mathrm{M}}$ and $\mathrm{NDVI}_{\mathrm{D}}$ surfaces compared to the $\mathrm{DTB}_{\mathrm{C} 6}$ and $\mathrm{DTB}_{\mathrm{C} 6.1}$. Overall, the performance of the $\mathrm{DTB}_{\mathrm{SMS}}$ was better than the $\mathrm{DTB}_{\mathrm{C} 6}$ and $\mathrm{DTB}_{\mathrm{C} 6.1}$ for all the surfaces except for $\mathrm{NDVI}_{\mathrm{P}}$, where it is comparable with the DTB 6 .1. 


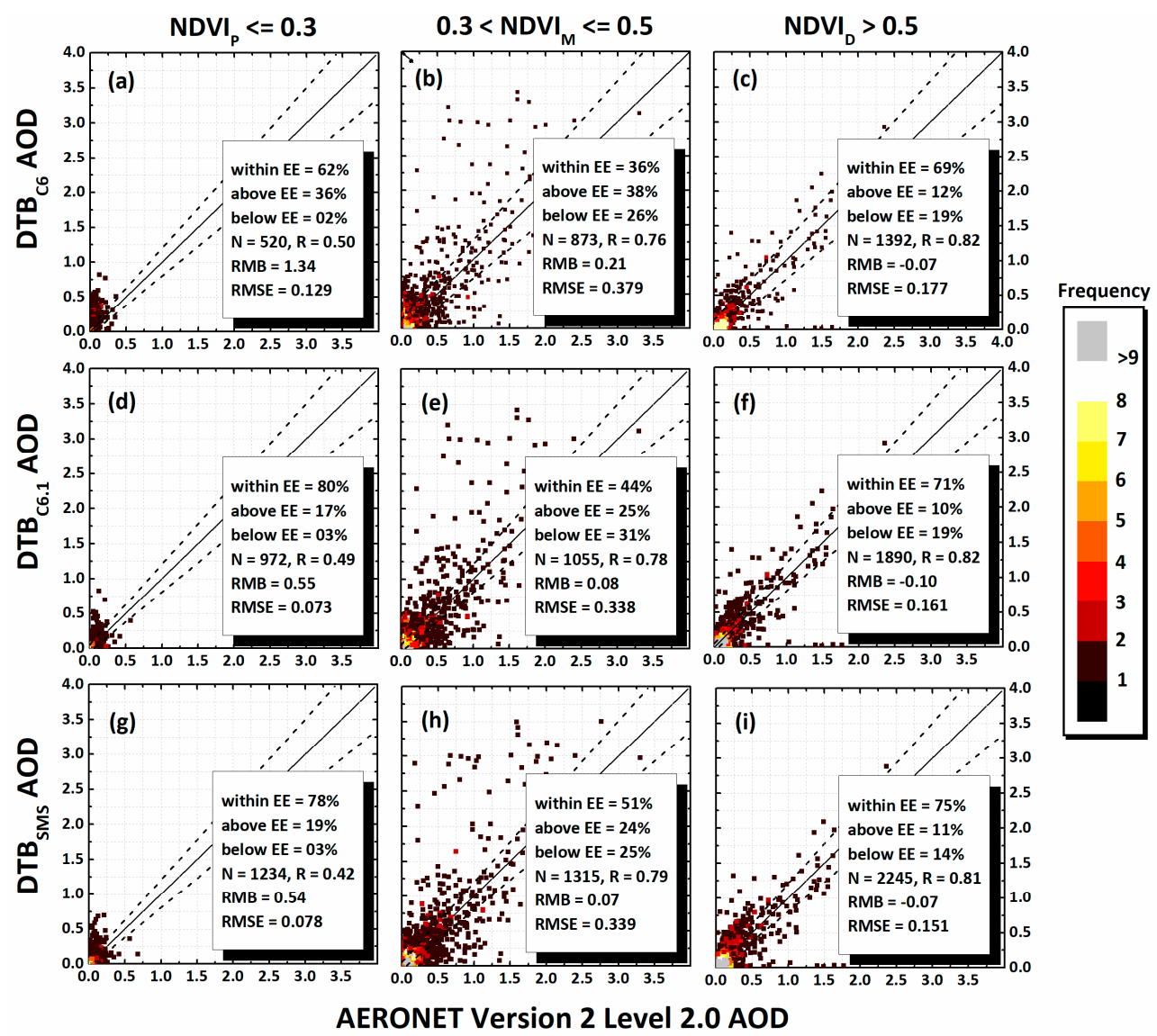

Figure 5. Same as Figure 1, but for South American sites.

\subsection{Validation of $D T B_{C 6}, D T B_{C 6.1}$, and $D T B_{S M S} A O D$ over Diverse Vegetated Surfaces at Global Scale}

At the global scale, validation of the $\mathrm{DTB}_{\mathrm{C} 6}, \mathrm{DTB}_{\mathrm{C} 6.1}$, and $\mathrm{DTB}_{\mathrm{SMS}}$ was conducted over 68 AEROENT sites located at diverse vegetated surfaces (Figure 6). The large numbers of AOD measurements from AERONET were available for $\mathrm{NDVI}_{\mathrm{M}}$ surfaces $(\mathrm{N}=27,476)$ followed by $\mathrm{NDVI}_{\mathrm{D}}$ surfaces $(N=19,286)$ and NDVI $_{P}$ surfaces $(N=15,135)$. These AOD measurements were available from January to December for all surface types. Fractions of the $\mathrm{DTB}_{\mathrm{C} 6}$ AOD retrievals coincident with AERONET AOD measurements were $45 \%, 47 \%$ and $48 \%$ for NDVI $_{P}$ (Figure $6 \mathrm{a}$ ), $\mathrm{NDVI}_{\mathrm{M}}$ (Figure $6 \mathrm{~b}$ ), and $\mathrm{NDVI}_{\mathrm{D}}$ (Figure $6 \mathrm{c}$ ) surfaces, respectively. The correlation coefficient of the $\mathrm{DTB}_{\mathrm{C} 6}$ retrievals with the AEROENT measurements was $\geq 0.80$ for all the surfaces, $60-63 \%$ of the retrievals were within the $\mathrm{EE}$, and $30-33 \%$ of the retrievals fell above the EE. The positive value of RMB indicates $21-30 \%$ average overestimation in the $\mathrm{DTB}_{\mathrm{C} 6} \mathrm{AOD}$ retrievals. These results suggest that the combination of estimated surface reflectance and aerosol models used in the $\mathrm{DT}_{\mathrm{C} 6}$ and $\mathrm{DB}_{\mathrm{C} 6}$ algorithm might has large errors, and overall, the performance of the $\mathrm{DTB}_{\mathrm{C} 6}$ was poor over diverse vegetated surfaces at a global scale.

For the DTB $\mathrm{C}_{6.1}$, fractions of observations coincident with AERONET AOD measurements were $65 \%$ for the $\mathrm{NDVI}_{\mathrm{P}}$ surfaces (Figure $6 \mathrm{~d}$ ), $65 \%$ for the $\mathrm{NDVI}_{\mathrm{M}}$ surfaces (Figure $6 \mathrm{e}$ ), and $66 \%$ of the $\mathrm{NDVI}_{\mathrm{D}}$ surfaces (Figure $6 \mathrm{f}$ ) which were increased by $20 \%, 18 \%$, and $18 \%$, respectively, compared to the $\mathrm{DTB}_{\mathrm{C} 6}$. The percentage of retrievals within the EE increased from $60 \%$ to $69 \%, 63 \%$ to $68 \%$, and $61 \%$ to $66 \%$, the RMSE decreased from 0.168 to $0.128,0.157$ to 0.148 , and 0.133 to 0.128 , and the RMB decreased from 0.22 to $0.05,0.21$ to 0.15 , and 0.30 to 0.23 for $\mathrm{NDVI}_{\mathrm{P}}, \mathrm{NDVI}_{\mathrm{M}}$ and $\mathrm{NDVI}_{\mathrm{D}}$ surfaces, respectively. The $\mathrm{DTB}_{\mathrm{C} 6.1}$ AOD retrievals meet the requirements of the $\mathrm{EE}$ only for $\mathrm{NDVI}_{\mathrm{P}}$ and $\mathrm{NDVI}_{\mathrm{M}}$ surfaces as $69 \%$ and $68 \%$ of the retrievals were within the EE, respectively, whereas $66 \%$ of the retrievals were above the EE for the $\mathrm{NDVI}_{\mathrm{D}}$ surfaces. 
For the $\mathrm{DTB}_{\mathrm{SMS}}$, results show significant improvements in spatiotemporal coverage at global

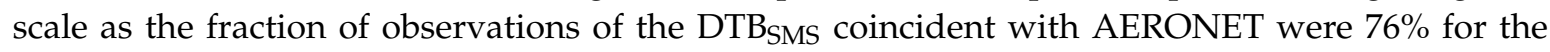
$\mathrm{NDVI}_{P}$ surfaces (Figure $6 \mathrm{~d}$ ), $78 \%$ for the $\mathrm{NDVI}_{\mathrm{M}}$ surfaces (Figure $6 \mathrm{e}$ ), and $79 \%$ for the $\mathrm{NDVI}_{\mathrm{D}}$ surfaces (Figure $6 \mathrm{f}$ ) which were increased by $11 \%(31 \%), 13 \%(31 \%)$, and $13 \%(31 \%)$, respectively, compared to the $\mathrm{DTB}_{\mathrm{C} 6.1}\left(\mathrm{DTB}_{\mathrm{C} 6}\right)$. The quality of the $\mathrm{DTB}_{\mathrm{SMS}} \mathrm{AOD}$ retrievals much improved as the percentage of retrievals within the EE increased by $6-9 \%$ (14-22\%), and RMB decreased by $30-100 \%(46-100 \%)$. Overall, the performance of the $\mathrm{DTB}_{\mathrm{SMS}}$ product was better than the $\mathrm{DTB}_{\mathrm{C} 6}$ and $\mathrm{DTB}_{\mathrm{C} 6.1} \mathrm{AOD}$ retrievals for $\mathrm{NDVI}_{\mathrm{P}}, \mathrm{NDVI}_{\mathrm{M}}$, and $\mathrm{NDVI}_{\mathrm{D}}$ surfaces at a global scale. These results suggest that the $\mathrm{DB}$ algorithm can retrieve accurate AOD over vegetated surfaces (NDVI $>0.3$ ), and similar results were also observed in our previous study [9]. Therefore it is recommended to consider the DB AOD retrievals for NDVI $>0.3$ in the operational merged DTB aerosol product.

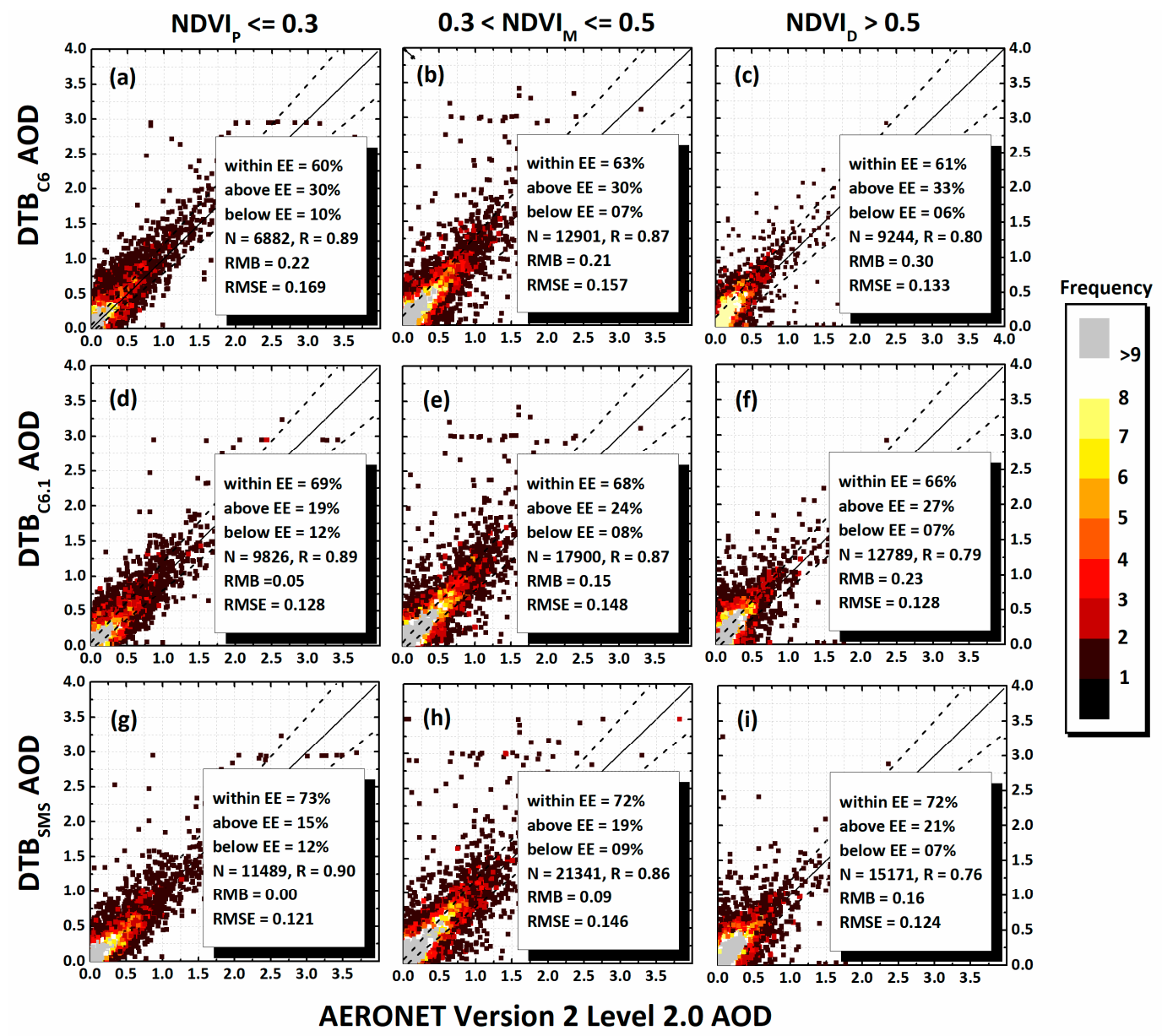

Figure 6. Same as Figure 1, but for 68 global sites.

For statistical significance, an equal number of AOD retrievals for the same geolocations (time and site) were selected from the $\mathrm{DTB}_{\mathrm{C} 6}, \mathrm{DTB}_{\mathrm{C} 6.1}$, and $\mathrm{DTB}_{\mathrm{SMS}}$ for all the surfaces and validated against the same AEROENT AOD measurements at the global scale (Figure 7). The percentage of the $\mathrm{DBT}_{\mathrm{C} 6}$ AOD retrievals within the EE was $<68 \%$, whereas, the AOD retrievals in the $\mathrm{DTB}_{\mathrm{C} 6.1}$ significantly improved as $68-70 \%$ of the retrievals were within the EE. Significant improvements were observed for the DTB ${ }_{S M S}$ in terms of large percentage within the EE, and small RMSE and RMB compared to the $\mathrm{DTB}_{\mathrm{C} 6}$ and $\mathrm{DTB}_{\mathrm{C} 6.1}$. The correlation coefficient for all the methods was same on a global scale. These results suggest that the DTB ${ }_{\mathrm{SMS}}$ is robust and better than the $\mathrm{DTB}_{\mathrm{C} 6}$ and $\mathrm{DTB}_{\mathrm{C} 6.1}$ for $\mathrm{NDVI}_{\mathrm{P}}$, $\mathrm{NDVI}_{\mathrm{M}}$, and $\mathrm{NDVI}_{\mathrm{D}}$ surfaces at a global scale and can be used operationally for generation of the merged DTB aerosol product. 


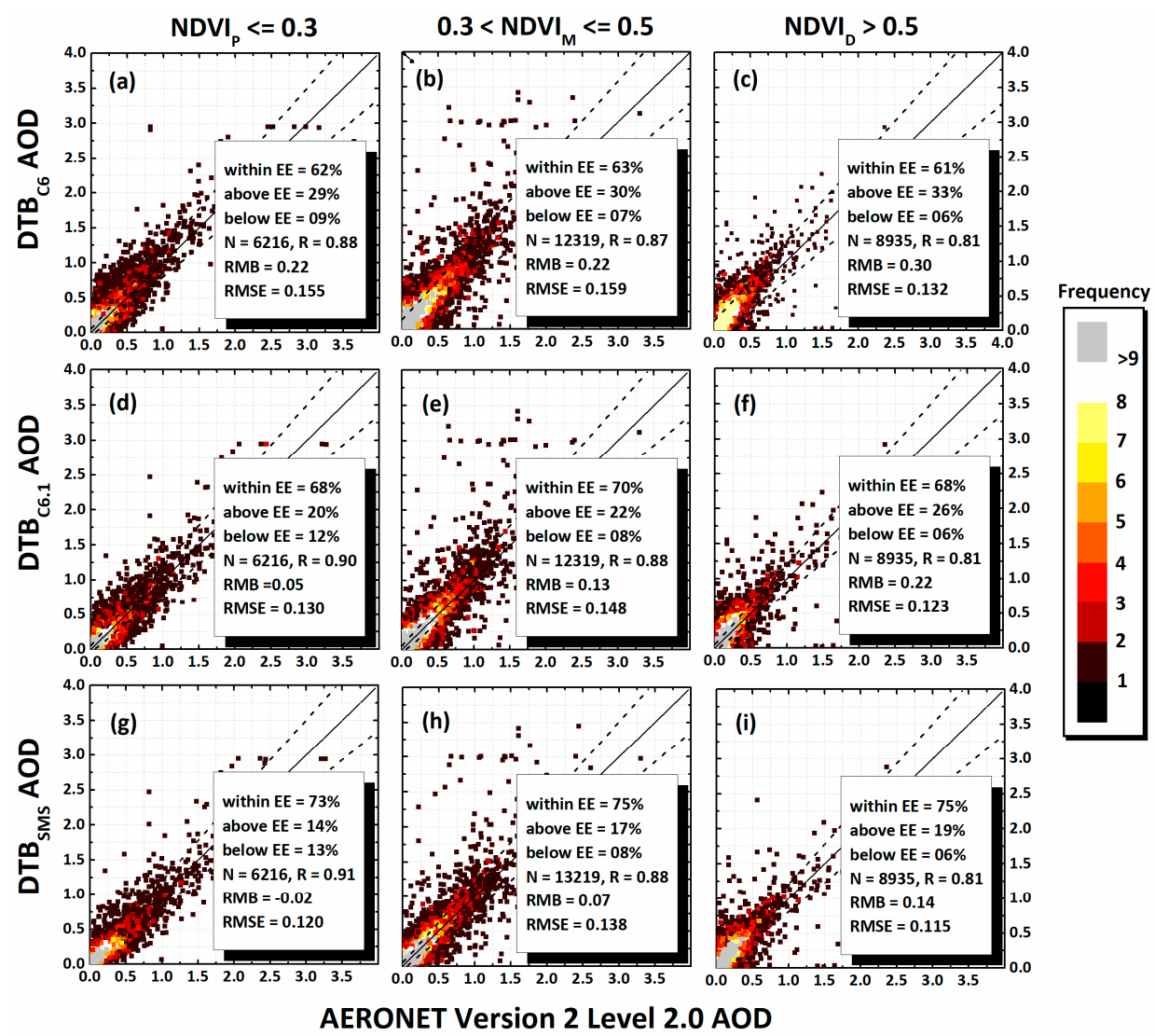

Figure 7. Validation of an equal number of the $\operatorname{DTB}_{\mathrm{C} 6}(\mathbf{a}-\mathbf{c}), \mathrm{DTB}_{\mathrm{C} 6.1}(\mathbf{d}-\mathbf{f})$ and $\mathrm{DTB}_{\mathrm{SMS}}(\mathbf{g}-\mathbf{i}) \mathrm{AOD}$ retrievals for the same geolocations (time and place) against the same AERONET L2 V2 AOD measurements for 68 global sites located over $\mathrm{NDVI}_{\mathrm{P}}, \mathrm{NDVI}_{\mathrm{M}}$, and $\mathrm{NDVI}_{\mathrm{D}}$ surfaces. Where dashed lines represent the EE envelope and the solid line represents the 1:1 line.

\section{Discussion}

In general, under- and over-estimation in satellite AOD retrievals during clear sky or in the presence of thin aerosol layer are mainly due to over- and under-estimation in the estimated surface reflectance used for aerosol inversion which has more contributions in the TOA reflectance compared to atmospheric path reflectance. Similarly, under- and over-estimation in satellite AOD retrievals in the presence of heavy or thick aerosol layer are mainly due to errors in the aerosol models used in the creation of look-up-table (LUT) for aerosol inversion as the atmospheric path reflectance has more contributions in the TOA reflectance compared to the surface reflectance. These general rules are applicable to all of the available satellites aerosol products, irrespective of their available old and new collections or versions, and such findings have been reported in previous studies [19-22]. Good agreement or high correlation between satellite AOD retrievals and AERONET AOD measurements indicate that the satellite AOD observations follow the same variations in aerosol concentrations as measured by AERONET. However, low correlation and a large percentage of the retrievals within the EE indicate that the satellite AOD observation does not follow the same variations in aerosol concentrations as measured by AERONET but these observations have a small difference and comparable results with AERONET measurements in values $[8,9,11]$.

This study has compared the MOD04 C6 and C6.1 merged aerosol products (DTB ${ }_{\mathrm{C} 6}$ and $\mathrm{DTB}_{\mathrm{C} 6.1}$ ) over the diverse vegetated surfaces using AERONET AOD measurements obtained from 68 global sites from 2004-2014. Additionally, the DTB ${ }_{\mathrm{SMS}}$ AOD retrievals were also included for comparison purposes, and these retrievals are different from the $\mathrm{DTB}_{\mathrm{C} 6 / \mathrm{C} 6.1} \mathrm{AOD}$ retrievals as the selection of DT 
and DB AOD retrievals for $\mathrm{DTB}_{\mathrm{C} 6 / \mathrm{C} 6.1}$ depends on NDVI $[2,8]$, whereas $\mathrm{DTB}_{\mathrm{SMS}}$ is independent of NDVI and includes all the available highest quality assurance DT and DB retrievals [9].

This section mainly discusses the impact of the modifications and improvements on the $\mathrm{DTB}_{\mathrm{C} 6.1}$ AOD retrievals which have been made for $\mathrm{C} 6.1$ compared to the $\mathrm{C} 6$. For $\mathrm{DT}_{\mathrm{C} 6.1}$, the major modification is the revised and improved ratios for the surface reflectance for the urban areas defined by MOD09 surface reflectance product [10]. For $\mathrm{DB}_{\mathrm{C} 6.1}$, the main modifications are (i) removal of artifacts from the heterogeneous terrain, (ii) improved surface modeling for elevated terrain, (iii) updated seasonal/regional aerosol models, and (iv) improved internal smoke detection masks.

Comparison for the Asian sites located over $\mathrm{NDVI}_{\mathrm{P}}, \mathrm{NDVI}_{\mathrm{M}}$ and $\mathrm{NDVI}_{\mathrm{D}}$ surfaces shows that the $\mathrm{DTB}_{\mathrm{C} 6}$ has more AOD retrievals over NDVI surfaces compared to the $\mathrm{NDVI}_{M}$ and $\mathrm{NDVI}_{\mathrm{D}}$ surface due to greater contribution by the DB AOD retrievals as it performs better and suitable to retrieve more observations than the DT over partially vegetated surfaces $[5,8,11,23]$. The high correlation coefficient for the $\mathrm{DTB}_{\mathrm{C} 6 / \mathrm{C} 6.1}$ and DTB $\mathrm{SMS}$ AOD retrievals with the AERONET measurements for all the surfaces (Figure 1) indicate that these AOD retrievals follow the variations in aerosol concentrations over the Asian sites. Similarly, large percentage of $\mathrm{DTB}_{\mathrm{C} 6 / \mathrm{C} 6.1}$ and $\mathrm{DTB}_{\mathrm{SMS}}$ AOD retrievals within the EE for $\mathrm{NDVI}_{\mathrm{M}}$ surfaces (Figure $1 \mathrm{~b}, \mathrm{e}, \mathrm{h}$ ) indicates that the DT AOD retrievals have small differences with the AERONET measurements for $0.3<\mathrm{NDVI} \leq 0.5$. Significant overestimation in $\mathrm{DTB}_{\mathrm{C} 6 / \mathrm{C} 6.1} \mathrm{AOD}$ retrievals for the $\mathrm{NDVI}_{\mathrm{D}}$ surfaces in the presence of low and high aerosol loadings might be caused by the errors in the estimated surface reflectance and aerosol modes used for aerosol inversion in the DT algorithm [20-27]. Although the new surface reflectance scheme [10] used in the $\mathrm{DT}_{\mathrm{C} 6.1}$ reduced the overestimation as the percentage of retrievals above the EE were decreased from $30-48 \%$ to $20-40 \%$, but it does not show significant improvements for all the surfaces, and more improvements are still required. The modifications and improvements in the $\mathrm{DB}_{\mathrm{C} 6.1}$ algorithm increased the number of collocations, percentage within the EE and reduced the RMSE and RMB in the DTBSMS compared to the $\mathrm{C} 6.1$ as the SMS considers both $\mathrm{DT}_{\mathrm{C} 6.1}$ and $\mathrm{DB}_{\mathrm{C} 6.1}$ for all the NDVI values [9], whereas the $\mathrm{DTB}_{\mathrm{C} 6.1}$ considers DB only for NDVI $<0.2[2,8]$. It is worth mentioning that the modifications in the $\mathrm{DB}_{\mathrm{C} 6.1}$ algorithm also led to the underestimation in the AOD retrievals as can be seen in Figure 1g,h.

It is worth mentioning that the $\mathrm{DTB}_{\mathrm{C} 6}$ and $\mathrm{DTB}_{\mathrm{C} 6.1}$ underestimate AOD for the NDVI $\leq 0.5$ surfaces of Africa which might be due to overestimation in the surface reflectance (Figure 2a,b,d,e) [20-22,24,25], whereas the estimated surface reflectance seems to be more consistent with the observations for surfaces with NDVI > 0.5 and the DT algorithm performed well over such types of surfaces as has also been reported by others [28,29]. The surface reflectance used in $\mathrm{DT}_{\mathrm{C} 6.1}$ might has more errors compared to the surface reflectance used in $\mathrm{DT}_{\mathrm{C} 6}$ as evident from Figure $2 \mathrm{~b}(\mathrm{RMB}=-0.08)$ and $2 \mathrm{e}(\mathrm{RMB}=-0.19)$ which contain only $\mathrm{DT}_{\mathrm{C} 6.1}$ AOD retrievals.

Significant improvements in $\mathrm{DTB}_{\mathrm{C} 6.1}$ and $\mathrm{DTB}_{\mathrm{SMS}}$ AOD retrievals for European sites are mainly due to the improvements in the $\mathrm{DT}_{\mathrm{C} 6.1}$ and $\mathrm{DB}_{\mathrm{C} 6.1}$ algorithms which led to large numbers of collocations, the greater percentage within the EE and small RMSE and RMB compared to the $\mathrm{DTB}_{\mathrm{C} 6}$ retrievals. The large error in AOD retrievals for $\mathrm{NDVI}_{\mathrm{D}}$ surfaces might be due to the errors in the estimated surface reflectance used in the $\mathrm{DT}_{\mathrm{C} 6 / \mathrm{C} 6.1}$ algorithms (Figure 3c,f,i) [20-22,24,25]. The improvements in $\mathrm{DB}_{\mathrm{C} 6.1}$ played a significant role in the $\mathrm{DTB}_{\mathrm{SMS}}$ retrievals as shown in Figure $3 \mathrm{~g}, \mathrm{~h}, \mathrm{i}$ which make it superior to the $\mathrm{DTB}_{\mathrm{C} 6.1}$. For $\mathrm{NDVI}_{\mathrm{P}}$ surfaces, improvements in the $\mathrm{DT}_{\mathrm{C} 6.1}$ algorithm increased the percentage of $\mathrm{DTB}_{\mathrm{SMS}}$ retrievals within the $\mathrm{EE}$, increased the number collocations, and decreased the RMB and RMSE, as these $\mathrm{DT}_{\mathrm{C} 6.1}$ retrievals were ignored by $\mathrm{DTB}_{\mathrm{C} 6.1}$ which were possibly available for NDVI $<0.2$ and $\mathrm{DTB}_{\mathrm{C} 6.1}$ consider only DB retrievals for these surfaces $[2,8]$.

The improvements in the $\mathrm{DT}_{\mathrm{C} 6.1}$ and $\mathrm{DB}_{\mathrm{C} 6.1}$ reduced the error only for the $\mathrm{NDVI}_{\mathrm{P}}$ surfaces of North America, whereas the new surface reflectance used in the $\mathrm{DT}_{\mathrm{C} 6.1}$ has not shown significant improvements in terms of high correlation, the large percentage within the EE, and small RMB and RMSE for the $\mathrm{NDVI}_{\mathrm{M}}$ and $\mathrm{NDVI}_{\mathrm{D}}$ surfaces. Overall, the $\mathrm{DT}_{\mathrm{C} 6.1}$ AOD retrievals used in $\mathrm{DTB}_{\mathrm{C} 6.1}$ performed poorly over North American sites might be due to significant errors in the estimated surface reflectance and aerosol model used in LUT. Whereas, the greater contributions of the modified DBC6.1 
AOD retrievals used in the $\mathrm{DTB}_{S M S}$ for $\mathrm{NDVI}_{M}$ and $\mathrm{NDVI}_{\mathrm{D}}$ surfaces improved the retrieval quality, increased the number of collocations and reduced the errors.

In the presence of high aerosol loadings over South American sites, the $\mathrm{DTB}_{\mathrm{C} 6}, \mathrm{DTB}_{\mathrm{C} 6.1}$, and DTB ${ }_{S M S}$ AOD retrievals were under- and over-estimated for $\mathrm{NDVI}_{\mathrm{M}}$ surfaces (Figure $5 \mathrm{~b}, \mathrm{e}, \mathrm{h}$ ) compared to the $\mathrm{NDVI}_{\mathrm{D}}$ surfaces (Figure $5 \mathrm{c}, \mathrm{f}, \mathrm{i}$ ), and the same pattern of significant underestimation was observed in $\mathrm{DTB}_{\mathrm{C} 6}, \mathrm{DTBC}_{6.1}$, and $\mathrm{DTBC}_{6.1}$ AOD for $\mathrm{NDVI}_{\mathrm{D}}$ surfaces. This might be due to the errors in the aerosol models used in LUT for the $\mathrm{DT}_{\mathrm{C} 6 / \mathrm{C} 6.1}$ algorithms. For low aerosol loadings, under- and over-estimation for $\mathrm{NDVI}_{\mathrm{P}} \mathrm{NDVI}_{\mathrm{M}}$ and $\mathrm{NDVI}_{\mathrm{D}}$ surfaces might be caused by over- and under-estimation in the estimated surface reflectance used in the $\mathrm{DB}_{\mathrm{C} 6 / \mathrm{C} 6.1}$ and $\mathrm{DT}_{\mathrm{C} 6 / \mathrm{C} 6.1}$ algorithms, respectively. So, true aerosol properties are important to retrieve accurate high AOD and true surface properties are important to retrieve accurate low AOD.

At the global scale, the high correlation coefficient of the $\mathrm{DTB}_{\mathrm{C} 6 / \mathrm{C} 6.1}$ and $\mathrm{DTB}_{\mathrm{SMS}}$ AOD retrievals with the AEROENT measurements for all surfaces indicate that the $\mathrm{DTB}_{\mathrm{C} 6 / \mathrm{C} 6.1}$ and $\mathrm{DTB}_{\mathrm{SMS}}$ follow the trend of actual variations in aerosol concentrations. Significant improvements in the DTB $\mathrm{B}_{\mathrm{C} .1}$ AOD retrievals compared to the $\mathrm{DTB}_{\mathrm{C} 6}$ is due to the new surface reflectance scheme used in the $\mathrm{DT}_{\mathrm{C} 6.1}$ and improvements in the $\mathrm{DB}_{\mathrm{C} 6.1}$ algorithm reduced the overestimation in the $\mathrm{DTB}_{\mathrm{C} 6.1} \mathrm{AOD}$ retrievals for the NDVIP surfaces as the percentage of retrievals above the EE decreased from $30 \%$ to $19 \%$. Overall, significant improvements in the DTB $_{\mathrm{SMS}}$, specifically for NDVI $>0.30$, was due to the great contributions of the $\mathrm{DB}_{\mathrm{C} 6.1}$ AOD retrievals, which were ignored by the $\mathrm{DTB}_{\mathrm{C} 6}$ and $\mathrm{DTB}_{\mathrm{C} 6.1}$ products $[2,8]$. For an equal number of collocations for the same time and sites, the DTB $\mathrm{SMS}_{\text {has }}$ better performance in terms of a large number of collocations, the greater percentage within the EE, small RMSE, and RMB as it considered all those available $\mathrm{AOD}$ retrievals either from $\mathrm{DT}_{\mathrm{C} 6.1}$ or $\mathrm{DB}_{\mathrm{C} 6.1}$ which were possibly ignored by DTB $_{\mathrm{C} 6.1}$ due to NDVI threshold criteria.

\section{Summary and Conclusions}

In this study, the $\mathrm{DTB}_{\mathrm{C} 6}, \mathrm{DTB}_{\mathrm{C} 6.1}$, and $\mathrm{DTB}_{\mathrm{SMS}} \mathrm{AOD}$ retrievals were validated at global scale from 2004-2014 against AERONET Version 2 Level 2.0 AOD measurements obtained from 68 sites located over diverse vegetated surfaces, i.e., partially/non-vegetated $\left(\mathrm{NDVI}_{P} \leq 0.3\right)$, moderately-vegetated $\left(0.3<\mathrm{NDVI}_{\mathrm{M}} \leq 0.5\right)$ and densely-vegetated $\left(\mathrm{NDVI}_{\mathrm{D}}>0.5\right)$ surfaces, categorized by static values of monthly NDVI observations obtained from the MOD13A3 C6 L3 product. The DTB $\mathrm{C}_{6}$ and DTB $_{\text {C6.1 }}$ AOD products are accomplished by the NDVI criteria [2]: (i) use the DT AOD retrievals for NDVI $>0.3$, (ii) use the DB AOD retrievals for NDVI $<0.2$, and (iii) use an average of the DT and DB AOD retrievals or the available one with highest quality assurance flag (DT: QAF $=3$; DB:

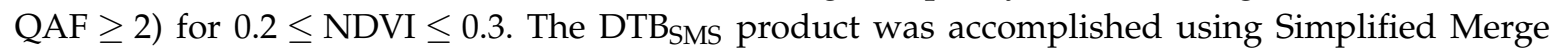
Scheme (SMS) $[9,17]$, i.e. use an average of the $\mathrm{DT}_{\mathrm{C} 6.1}$ and $\mathrm{DB}_{\mathrm{C} 6.1}$ highest quality assurance $\mathrm{AOD}$ retrievals or the available one for all values of NDVI. For this, only those DT and DB AOD retrievals at $550 \mathrm{~nm}$ passing recommended quality assurance checks were used (for DT, corresponding to retrievals flagged $\mathrm{QAF}=3$; for $\mathrm{DB}$, retrievals flagged $\mathrm{QAF} \geq 2$ ). Results showed that the number of coincident observations and the percentage of retrievals within/above/below the EE, and RMB were significantly improved for the $\mathrm{DTB}_{\mathrm{SMS}}$ at the regional to global scales, compared to the $\mathrm{DTB}_{\mathrm{C} 6}$ and DTB $_{C 6.1}$. The main outcomes of this study are:

(i) The $\mathrm{DTB}_{\mathrm{C} 6}$ and $\mathrm{DTB}_{\mathrm{C} 6.1} \mathrm{AOD}$ retrievals performed well for the sites located over $\mathrm{NDVI}_{\mathrm{M}}$ surfaces in Asia, whereas, large errors were observed for $\mathrm{NDVI}_{\mathrm{D}}$ surfaces might be due to errors in the estimated surface reflectance and aerosol models used for the $\mathrm{DT}_{\mathrm{C} 6}$ and $\mathrm{DT}_{\mathrm{C} 6.1}$ algorithm, as the $\mathrm{DTB}_{\mathrm{C} 6}$ and $\mathrm{DTB}_{\mathrm{C} 6.1}$ only have DT AOD retrievals for $\mathrm{NDVI}_{\mathrm{D}}$ surfaces. This suggests that the new ratios for surface reflectance estimation in the $\mathrm{DT}_{\mathrm{C} 6.1}$ do not significantly improve the AOD retrievals over $\mathrm{NDVI}_{\mathrm{D}}$ surfaces of Asia, and more improvements are required.

(ii) All the AOD retrievals performed well in terms of correlation and large percentage within the $\mathrm{EE}$, but significant underestimation was observed for the $\mathrm{DTB}_{\mathrm{C} 6.1}$ and DTB $\mathrm{SMS}_{\mathrm{S}}$ AOD retrievals 
over $\mathrm{NDVI}_{\mathrm{P}}$ and $\mathrm{NDVI}_{\mathrm{M}}$ surfaces of Africa which might be due to overestimation in the newly estimated surface reflectance used in the $\mathrm{DT}_{\mathrm{C} 6.1}$ algorithm.

(iii) For European sites, the $\mathrm{DTB}_{\mathrm{C} 6}$ AOD retrievals performed well for the sites located over $\mathrm{NDVI}_{\mathrm{M}}$ surfaces compared to the $\mathrm{NDVI}_{\mathrm{P}}$ and $\mathrm{NDVI}_{\mathrm{D}}$ surfaces in terms of a large number of observations, the large percentage within the EE, and small RMSE. Whereas, the performance of the $\mathrm{DTB}_{\mathrm{C} 6.1}$ $\mathrm{AOD}$ retrievals was better than the $\mathrm{DTB}_{\mathrm{C} 6}$ due to improved surface reflectance scheme used in the $\mathrm{DT}_{\mathrm{C} 6.1}$.

(iv) The $\mathrm{DTB}_{\mathrm{C} 6}$ and $\mathrm{DTB}_{\mathrm{C} 6.1} \mathrm{AOD}$ retrievals have a large error for the sites located over $\mathrm{NDVI}_{\mathrm{M}}$ surfaces of North America during low to high aerosol loadings which suggests that significant improvements are required in the surface reflectance method and aerosol models used in the DT algorithm.

(v) For South American sites, significant improvements are required in $\mathrm{DT}_{\mathrm{C} 6.1}$ AOD retrievals, especially for $\mathrm{NDVI}_{\mathrm{M}}$ surfaces as less than $60 \%$ of the retrievals, were within the $\mathrm{EE}$.

(vi) The $\mathrm{DTB}_{\mathrm{SMS}}$ is robust and performed better than the $\mathrm{DTB}_{\mathrm{C} 6}$ and $\mathrm{DTB}_{\mathrm{C} 6.1}$ for all types of land surfaces used in this study, and significantly improved the number of observations, the percentage of retrievals within the EE, and RMB at the regional scale.

(vii) At the global scale, the $\mathrm{DTB}_{\mathrm{C} 6}$ has low retrieval quality as $\mathrm{AOD}$ retrievals do not meet the requirements of the $\mathrm{EE}(<68 \%)$ for diverse vegetated surfaces, whereas the $\mathrm{DT}_{\mathrm{C} 6.1}$ has better performance for the $\mathrm{NDVI}_{\mathrm{P}}$ and $\mathrm{NDVI}_{\mathrm{M}}$ surfaces, but still improvements are required for $\mathrm{NDVI}_{\mathrm{D}}$ surfaces. The DTB $\mathrm{SMS}_{\mathrm{S}}$ AOD retrievals meet the requirements of the EE (72-73\%) with more available collocations, and small RMSE and RMB, compared to the $\mathrm{DTB}_{\mathrm{C} 6}$ and $\mathrm{DTB}_{\mathrm{C} 6.1}$.

These results suggest that the DB AOD retrievals should be considered over moderate and dense vegetated surfaces (NDVI > 0.3) in the operational merged DTB AOD product because sometimes, the DT algorithm does not perform well over these surfaces, and the inclusion of DB can improve the retrievals quality and reduce the errors in the merged product.

Acknowledgments: The authors would like to acknowledge NASA Goddard Space Flight Center for MODIS data, and Principal Investigators of AERONET sites. We are thankful to Devin White (Oak Ridge National Laboratory) for MODIS Conversion Tool Kit (MCTK). The National Key Research and Development Program of China (No. 2016YFC1400901), the Research Grants Council (RGC) (Project Nos. PolyU 152043/14E and PolyU 152232/17E), and National Science Foundation of China (NSFC) (Project No. 41374013) have sponsored this research.

Author Contributions: Muhammad Bilal designed and wrote the paper; Majid Nazeer, Zhongfeng Qiu, and Xiaoli Ding reviewed and modified the paper, and Majid Nazeer and Jing Wei helped in data processing.

Conflicts of Interest: The authors declare no conflict of interest.

\section{Appendix A. Abbreviations}

The following abbreviations are used in this manuscript:

$\begin{array}{ll}\text { AERONET } & \text { Aerosol Robotic Network } \\ \text { AOD } & \text { Aerosol Optical Depth } \\ \text { C6 } & \text { Collection 6 } \\ \text { DAAC } & \text { Distributed Active Archive Center } \\ \text { DB } & \text { Deep Blue } \\ \text { DT } & \text { Dark Target } \\ \text { DTB } & \text { Dark Target and Deep Blue combined aerosol product } \\ \text { EE } & \text { Expected Error } \\ \text { LAADS } & \text { Level-1 and Atmosphere Archive \& Distribution System } \\ \text { LUT } & \text { Look Up Table } \\ \text { L1 } & \text { Level-1 } \\ \text { L2 } & \text { Level-2 } \\ \text { L3 } & \text { Level-3 }\end{array}$




$\begin{array}{ll}\text { MODIS } & \text { Moderate Resolution Imaging Spectroradiometer } \\ \text { MOD13A3 } & \text { MODIS C6 monthly level-3 Normalized Difference Vegetation Index product } \\ \text { MOD04 } & \text { MODIS level-2 operational aerosol product for Terra } \\ \text { MYD04 } & \text { MODIS level-2 operational aerosol product for Aqua } \\ \text { N } & \text { Number of collocations } \\ \text { NDVI } & \text { Normalized Difference Vegetation Index } \\ \text { NDVI }_{D} & \text { NDVI over densely-vegetated surfaces } \\ \text { NDVI }_{M} & \text { NDVI over moderately-vegetated surfaces } \\ \text { NDVIP } & \text { NDVI over partially/non-vegetated surfaces } \\ \text { QAF } & \text { Quality Assurance Flag } \\ \text { RMB } & \text { Relative Mean Bias } \\ \text { SDS } & \text { Scientific Data Set } \\ \text { SMS } & \text { Simplified Merge Scheme } \\ \text { TOA } & \text { Top of Atmosphere reflectance } \\ \text { V2 } & \text { Version } 2 \\ \alpha 440-675 & \AA\end{array}$

\section{References}

1. Kaufman, Y.J.; Wald, A.E.; Remer, L.A.; Bo-Cai, G.; Rong-Rong, L.; Flynn, L. The MODIS 2.1- $\mu \mathrm{m}$ channel-correlation with visible reflectance for use in remote sensing of aerosol. IEEE Trans. Geosci. Remote Sens. 1997, 35, 1286-1298. [CrossRef]

2. Levy, R.C.; Mattoo, S.; Munchak, L.A.; Remer, L.A.; Sayer, A.M.; Patadia, F.; Hsu, N.C. The collection 6 modis aerosol products over land and ocean. Atmos. Meas. Tech. 2013, 6, 2989-3034. [CrossRef]

3. Levy, R.C.; Remer, L.A.; Mattoo, S.; Vermote, E.F.; Kaufman, Y.J. Second-generation operational algorithm: Retrieval of aerosol properties over land from inversion of moderate resolution imaging spectroradiometer spectral reflectance. J. Geophys. Res. 2007, 112, D13211. [CrossRef]

4. Tanré, D.; Kaufman, Y.J.; Herman, M.; Mattoo, S. Remote sensing of aerosol properties over oceans using the modis/eos spectral radiances. J. Geophys. Res. Atmos. 1997, 102, 16971-16988. [CrossRef]

5. Hsu, N.C.; Jeong, M.-J.; Bettenhausen, C.; Sayer, A.M.; Hansell, R.; Seftor, C.S.; Huang, J.; Tsay, S.-C. Enhanced deep blue aerosol retrieval algorithm: The second generation. J. Geophys. Res. Atmos. 2013, 118, 9296-9315. [CrossRef]

6. Hsu, N.C.; Tsay, S.-C.; King, M.D.; Herman, J.R. Deep blue retrievals of Asian aerosol properties during ace-asia. IEEE Trans. Geosci. Remote Sens. 2006, 44, 3180-3195. [CrossRef]

7. Hsu, N.C.; Tsay, S.-C.; King, M.D.; Herman, J.R. Aerosol properties over bright-reflecting source regions. IEEE Trans. Geosci. Remote Sens. 2004, 42, 557-569. [CrossRef]

8. Sayer, A.M.; Munchak, L.A.; Hsu, N.C.; Levy, R.C.; Bettenhausen, C.; Jeong, M.J. MODIS collection 6 aerosol products: Comparison between aqua's e-deep blue, dark target, and "merged" data sets, and usage recommendations. J. Geophys. Res. Atmos. 2014, 119, 13965-13989. [CrossRef]

9. Bilal, M.; Nichol, J.; Wang, L. New customized methods for improvement of the MODIS c6 dark target and deep blue merged aerosol product. Remote Sens. Environ. 2017, 197, 115-124. [CrossRef]

10. Gupta, P.; Levy, R.C.; Mattoo, S.; Remer, L.A.; Munchak, L.A. A surface reflectance scheme for retrieving aerosol optical depth over urbansurfaces in modis dark target retrieval algorithm. Atmos. Meas. Tech. 2016, 9 , 3293-3308. [CrossRef]

11. Sayer, A.M.; Hsu, N.C.; Bettenhausen, C.; Jeong, M.-J. Validation and uncertainty estimates for MODIS collection 6 "deep blue" aerosol data. J. Geophys. Res. Atmos. 2013, 118, 7864-7872. [CrossRef]

12. Holben, N.; Tanr, D.; Smirnov, A.; Eck, T.F.; Slutsker, I.; Newcomb, W.W.; Schafer, J.S.; Chatenet, B.; Lavenu, F.; Kaufman, J.; et al. An emerging ground-based aerosol climatology: Aerosol optical depth from aeronet. J. Geophys. Res. Atmos. 2001, 106, 12067-12097. [CrossRef]

13. Holben, B.N.; Eck, T.F.; Slutsker, I.; Tanré, D.; Buis, J.P.; Setzer, A.; Vermote, E.; Reagan, J.A.; Kaufman, Y.J.; Nakajima, T.; et al. Aeronet-A federated instrument network and data archive for aerosol characterization. Remote Sens. Environ. 1998, 66, 1-16. [CrossRef] 
14. Román, R.; Antón, M.; Valenzuela, A.; Gil, J.E.; Lyamani, H.; Miguel, A.D.; Olmo, F.J.; Bilbao, J.; Alados-Arboledas, L. Evaluation of the desert dust effects on global, direct and diffuse spectral ultraviolet irradiance. Tellus B 2013. [CrossRef]

15. Mateos, D.; Bilbao, J.; Kudish, A.I.; Parisi, A.V.; Carbajal, G.; di Sarra, A.; Román, R.; de Miguel, A. Validation of omi satellite erythemal daily dose retrievals using ground-based measurements from fourteen stations. Remote Sens. Environ. 2013, 128, 1-10. [CrossRef]

16. Smirnov, A.; Holben, B.N.; Eck, T.F.; Dubovik, O.; Slutsker, I. Cloud-screening and quality control algorithms for the aeronet database. Remote Sens. Environ. 2000, 73, 337-349. [CrossRef]

17. Bilal, M.; Qiu, Z.; Campbell, J.R.; Spak, S.; Shen, X.; Nazeer, M. A New MODIS C6 Dark Target and Deep Blue Merged Aerosol Product on a 3 km Spatial Grid. Remote Sens. 2018, 10, 463. [CrossRef]

18. Bilal, M.; Nichol, J. Evaluation of the NDVI-Based Pixel Selection Criteria of the MODIS C6 Dark Target and Deep Blue Combined Aerosol Product. IEEE J. Sel. Top. Appl. Earth Obs. Remote Sens. 2017, 10, 3448-3453. [CrossRef]

19. Li, Z.; Li, L.; Zhang, F.; Li, D.; Xie, Y.; Xu, H. Comparison of aerosol properties over Beijing and Kanpur: Optical, physical properties and aerosol component composition retrieved from 12 years ground-based sun-sky radiometer remote sensing data. J. Geophys. Res. Atmos. 2015, 120, 1520-1535. [CrossRef]

20. Xie, Y.; Zhang, Y.; Xiong, X.; Qu, J.J.; Che, H. Validation of MODIS aerosol optical depth product over china using carsnet measurements. Atmos. Environ. 2011, 45, 5970-5978. [CrossRef]

21. He, Q.; Li, C.; Tang, X.; Li, H.; Geng, F.; Wu, Y. Validation of MODIS derived aerosol optical depth over the yangtze river delta in china. Remote Sens. Environ. 2010, 114, 1649-1661. [CrossRef]

22. Li, Z.; Niu, F.; Lee, K.-H.; Xin, J.; Hao, W.M.; Nordgren, B.L.; Wang, Y.; Wang, P. Validation and understanding of moderate resolution imaging spectroradiometer aerosol products (c5) using ground-based measurements from the handheld sun photometer network in China. J. Geophys. Res. 2007, 112. [CrossRef]

23. Bilal, M.; Nichol, J.E. Evaluation of modis aerosol retrieval algorithms over the Beijing-Tianjin-Hebei region during low to very high pollution events. J. Geophys. Res. Atmos. 2015, 120, 7941-7957. [CrossRef]

24. Bilal, M.; Nichol, J.E.; Chan, P.W. Validation and accuracy assessment of a simplified aerosol retrieval algorithm (SARA) over Beijing under low and high aerosol loadings and dust storms. Remote Sens. Environ. 2014, 153, 50-60. [CrossRef]

25. Chu, D.A.; Kaufman, Y.J.; Ichoku, C.; Remer, L.A.; Tanré, D.; Holben, B.N. Validation of MODIS aerosol optical depth retrieval over land. Geophys. Res. Lett. 2002, 29, 8007. [CrossRef]

26. He, L.; Wang, L.; Lin, A.; Zhang, M.; Bilal, M.; Wei, J. Performance of the npp-viirs and aqua-MODIS aerosol optical depth products over the Yangtze River basin. Remote Sens. 2018, 10, 117. [CrossRef]

27. Wei, J.; Sun, L.; Huang, B.; Bilal, M.; Zhang, Z.; Wang, L. Verification, improvement and application of aerosol optical depths in china part 1: Inter-comparison of NPP-VIIRS and aqua-MODIS. Atmos. Environ. 2018, 175, 221-233. [CrossRef]

28. Bilal, M.; Nichol, J.E.; Nazeer, M. Validation of aqua-MODIS c051 and c006 operational aerosol products using aeronet measurements over Pakistan. IEEE J. Sel. Top. Appl. Earth Obs. Remote Sens. 2016, 9, 2074-2080. [CrossRef]

29. Nichol, J.; Bilal, M. Validation of MODIS $3 \mathrm{~km}$ resolution aerosol optical depth retrievals over Asia. Remote Sens. 2016, 8, 328. [CrossRef]

(C) 2018 by the authors. Licensee MDPI, Basel, Switzerland. This article is an open access article distributed under the terms and conditions of the Creative Commons Attribution (CC BY) license (http://creativecommons.org/licenses/by/4.0/). 